\title{
De volta À Senhora de Pangim: outras FONTES E OUTRAS REPRESENTAÇÕES
}

\author{
Back to the lady of Pangim: other sources and other representations
}

\author{
Mário CÉSAR LUGarinho ${ }^{1}$ \\ Helder Thiago Maia ${ }^{1}$ \\ ${ }^{1}$ Universidade de São Paulo. São Paulo, SP, Brasil. \\ E-mail: lugarinho@usp.br \\ E-mail: helderthiagomaia@usp.br
}

\section{RESUMO}

Este artigo apresenta duas seções que, apesar de distintas, estão conectadas pelo objeto comum, o romance A Senhora de Pangim, do autor integralista brasileiro Gustavo Barroso, publicado, no Brasil, em 1932, e, em Portugal em 1940. Na primeira sessão são analisados estudos de fundo histórico e literário, publicado entre 1932 e 1965. Na segunda seção são analisadas representações gráficas da personagem histórica de Baltasar do Couto Cardoso/Maria Úrsula de Abreu e Lencastro (1682-1730), com especial interesse para duas revistas em quadrinhos, uma brasileira Edição Maravilhosa, n. 116, publicada em 1956, e uma mexicana Mujeres Célebres, n. 57, publicada em 1965. Estamos interessados não só em pensar as reiterações e rupturas entre

EDITOR-CHEFE:

Gerson Roberto Neumann

EDITOR EXECUTIVO:

Regina Zilberman

SUBMETIDO: 30.04 .2021

ACEITO: 15.06 .2021

\section{COMO CITAR:}

LUGARINHO, Mário

César; MAIA, Helder

Thiago. De volta À Senhora

de Pangim: outras fontes

e outras representações.

Revista Brasileira de

Literatura Comparada, v. 23 , n. 44 , p. $120-147$, set.dez., 2021. doi: https:// doi.org/10.1590/2596$304 \times 20212344 \mathrm{mlhm}$ o discurso histórico e o discurso literário, mas também a discussão sobre donzelas-guerreiras e a maneira como essas representações consideraram a instabilidade de gênero da personagem.

PALAVRAS-CHAVE: Baltasar do Couto Cardoso; Maria Úrsula de Abreu e Lencastro; donzelasguerreiras; ficção; história; quadrinhos.

\section{ABSTRACT}

This article presents two sections that, although distinct, are connected by the common object, the novel A Senhora de Pangim (The lady of Pangim), by Brazilian integralist writer Gustavo Barroso, published in Brazil in 1932 and Portugal in 1940. In the first session, we analyze historical and literary studies, published between 1932 and 1965. In the second section, we exam graphic representations of the historical character of Baltasar do Couto Cardoso / Maria Úrsula de Abreu and Lencastro (1682-1730), with special interest for two comic magazines, Brazilian Edição Maravilhosa (Wonderful Edition), n. 116, published in 1956, and Mexican Mujeres Célebres (Celebrated Women), n 57, published in 1965. We are interested not only in thinking about the reiterations and ruptures between historical and literary discourse but also in the discussion about warrior maidens and the way these representations considered the character's gender instability.

KEYWORDS: Baltasar do Couto Cardoso; Maria Úrsula de Abreu e Lencastro; warrior maidens; novel; history; comics. 


\section{A SENHORA DE PANGIM}

Nossa personagem nasceu em 1682, na cidade do Rio de Janeiro e recebeu o nome de Maria Úrsula de Abreu e Lencastro ${ }^{1}$. Aos 18 anos, em $1^{\circ}$ de setembro de 1700, assentou praça em Lisboa como o soldado Baltasar do Couto Cardoso, tendo servido no exército colonial português, em Portugal e na Índia Portuguesa, por quase 14 anos. Pelo seu excelente desempenho militar, primeiro como soldado e depois como cabo, recebeu, como Maria Úrsula, o reconhecimento do Império Português através de uma pensão e da mercê do Paço de Pangim por seis anos. Algumas fontes históricas afirmam ainda que morreu provavelmente em 1730, casada com Afonso Teixeira Arrais de Melo, sem nunca ter abandonado os trajes masculinos e a espada.

Neste artigo, para entender como Baltasar/Maria Úrsula é construído literariamente, analisaremos representações gráficas sobre a personagem, com especial interesse para duas revistas em quadrinhos que narram e ficcionalizam a sua vida, a revista brasileira Edição Maravilhosa, n. 116, publicada em 1956 (BARROSO; MONTEIRO, 1956), e a revista mexicana Mujeres Célebres, n. 57, publicada em 1965 (HARRELL, 1965). Além disso, analisaremos as duas revistas em diálogo com o romance A Senhora de Pangim (1932), de Gustavo Barroso. Na leitura entre os três textos, os quais são as únicas obras de cunho literário sobre Baltasar/Maria Úrsula, estamos interessados em analisar principalmente como é narrada a transição de gênero vivida pela personagem. É importante dizer que a transição é descrita desde o primeiro relato histórico conhecido sobre Baltasar/Maria Úrsula, publicado em 24 de março de 1718 pela Gazeta de Lisboa (MAIA, 2020).

Interessa-nos também analisar os textos literários em diálogo com relatos históricos, uma vez que buscamos inferir as continuidades e as rupturas entre o discurso histórico e o discurso literário. $\mathrm{O}$ romance de Gustavo Barroso foi analisado em artigo anterior por Mário Lugarinho (2019), seguido por Helder Maia (2020), no qual foram analisados os 18 textos históricos publicados entre 1718 e $1931^{2}$. Sem perder de vista ambas as análises, estamos interessados agora nos textos publicados entre $1932 \mathrm{e}$ 1965, o que corresponde a 15 textos publicados entre a obra de Barroso (1932) e a publicação da revista mexicana (1965). Esse novo recorte visa não só analisar, em continuidade com os estudos anteriores, um novo conjunto de textos históricos, mas se preocupa também em pensar o diálogo entre história e literatura a partir de publicações imediatamente mais próximas no tempo. É também parte dos nossos interesses pensar Baltasar/Maria Úrsula a partir da discussão da crítica literária brasileira e portuguesa sobre “donzelas-guerreiras”. Não só preenchemos um vazio, uma vez que a personagem, ainda que seja recorrentemente apontada como uma donzela-guerreira (GALVÃO, 1998, 2016; SILVA, 2010), é efetivamente pouco estudada, tanto do ponto de vista literário como do ponto de vista histórico, mas, além disso, propomos também uma nova leitura para a tradição crítica sobre as donzelas-guerreiras.

Podemos dizer que os textos e personagens apontados (exageradamente) pela crítica literária como donzelas-guerreiras vivem quatro experiências de gênero que são significativamente distintas, e, por

1 Os nomes Baltasar do Couto Cardoso e Maria Úrsula de Abreu e Lencastro são escritos de diferentes formas, assim como a toponímia goesa. Optamos ao longo deste artigo por usar o nome e a grafia indicada pelo texto com o qual estamos dialogando.

2 O estudo de Maia (2020) alcança desde um primeiro relato encontrado sobre a personagem histórica (1718) e o último texto publicado antes do romance de Barroso (1931). O estudo de Lugarinho (2018), além de estudar o contexto de publicação das edições brasileira (1932) e portuguesa (1940), destaca a submissão da edição portuguesa às diretrizes da ordem de gênero tal como definida pelo Estado Novo português (1933-1974). 
isso, precisam ser distinguidas sob o risco não só de perdermos a potencialidade que essas personagens possuem de borrar e ultrapassar o binarismo de gênero, mas também sob o risco de seguirmos lendo essas personagens unicamente como mulheres cisgêneras ${ }^{3}$.

Ainda que as duas características principais - a transição de gênero e ir à guerra - das donzelasguerreiras sejam bastante específicas, na tradição da crítica literária sobre donzelas-guerreiras há, em nossa perspectiva, as "mulheres masculinas", personagens que não foram à guerra e nem viveram como homens, como Luzia-Homem (1903), de Domingos Olímpio; há as “mulheres guerreiras”, personagens que não viveram como homens, mas foram à guerra, como as narrativas em torno de Anita Garibaldi; há as "donzelas-guerreiras", personagens que foram à guerra e que viveram como homens unicamente durante a guerra, como no romanceiro ibérico; e há as "transgeneridades guerreiras", personagens que foram à guerra e que viveram sempre que possível como homens, como Diadorim (ROSA, 1956). Isso posto, pretendemos pensar o lugar ocupado por Baltasar/Maria Úrsula dentro dessa perspectiva crítica, assim como dentro dessas performatividades de gênero.

\section{NOVAS FONTES SOBRE BALTASAR/MARIA ÚRSULA}

Os textos históricos portugueses sobre Baltasar/Maria Úrsula, publicados entre 1718 e 1931, não se preocupam em explicar as motivações da personagem nem para a transição de gênero nem para ir à guerra. De forma contrária, os textos históricos brasileiros, do mesmo período, quase unanimemente, descrevem, de três formas, as motivações da personagem, seja para a transição de gênero, seja para a vida como soldado. A primeira, inaugurada em 1841, por Joaquim Norberto Souza Silva, narra as motivações da personagem a partir de três características que lhe seriam particulares, a "índole extremamente belicosa", o "ardente desejo de assignalar-se nos campos da guerra" e o "coração varonil" (SOUZA SILVA, 1841, p. 226); a segunda, de caráter mais melodramático e romântico, inaugurada em 1876, por Joaquim Manoel de Macedo, explica as motivações a partir de um "ardente amor contrariado" (MACEDO, 1876, p. 1); a terceira, inaugurada em 1899, por Ignez Sabino, de perspectiva médicopsiquiátrica, moralista e patológica, narra as motivações da personagem a partir de uma "vocação" abjeta e doentia e de um "desejo ardente de servir à pátria" (SABINO, 1899, p. 89). De forma geral, podemos dizer que as tentativas da historiografia brasileira em explicar as causas e motivações da transição de gênero e da vida como soldado de Baltasar/Maria Úrsula, ao mesmo tempo em que domesticam a personagem a partir de uma ideia de excepcionalidade e de heroicidade, reafirmam também a mulheridade, entendendo a transição como uma impossibilidade ontológica.

Além disso, a maior parte dos relatos históricos portugueses, com exceção do texto de Damião de Froes Perim (1740), não narram um possível casamento, assim como também não descrevem como a personagem viveu depois de dar baixa como soldado. De forma contrária, os relatos históricos brasileiros reafirmam quase unanimemente a versão de Froes Perim (1740), o que significa não só a reafirmação do casamento, mas também a ideia de que seguiu trajando "roupas varonis" e espada. Inovam ao afirmar que Baltasar/Maria Úrsula teria morrido cercado de glória e gozando de grande fama entre seus contemporâneos, ao contrário dos textos portugueses que sobre esse aspecto nada

3 Sobre como a crítica brasileira tem lido as donzelas-guerreiras, e mais detalhes sobre as quatro experiências de gênero vividas por elas, consultar Maia (2018). 
tratam. Podemos destacar, portanto, o maior interesse da historiografia brasileira em construir a personagem como uma heroína. É importante dizer também que os relatos brasileiros recorrem ao casamento como uma forma de reafirmar a mulheridade, e, para isso, atribuem a manutenção do traje varonil e da espada, mesmo após o casamento, à vaidade ou à saudade, sugeridas como características tipicamente femininas ${ }^{4}$.

A crítica literária de A Senhora de Pangim, de Mario Melo, publicada em 30 de abril de 1932, no Diario de Pernambuco, ao mesmo tempo em que analisa o romance de Gustavo Barroso (1932), também recupera relatos históricos sobre a personagem, especialmente o texto do Barão de Rio Branco (1891). Assim, mesmo que não busque explicar as motivações de Baltasar/Maria Úrsula, entende a transição de gênero e a vida como soldado como "disfarce", como faz o famoso diplomata (RIO BRANCO, 1891, p. 2), ainda que também afirme que a personagem foi autorizada a seguir usando "vestes masculinas" e espada (MELO, 1932, p. 3), o que significa que não há uma nova transição para uma feminilidade tradicional, e talvez explique a afirmação do autor de que se trata de uma "mulher homem".

Sobre o romance de Barroso, diz que o livro é "mais uma vitória, nas letras, desse escritor que apresenta, na atualidade, uma das maiores e mais variadas bagagens literárias no país” (MELO, 1932, p. 3). No entanto, ao contrário da própria obra, afirma que o amor entre Baltasar/Maria Úrsula e seu capitão nasceu da intimidade experimentada durante a convalescência do soldado, que havia sido ferido em combate, e após a transição de gênero ser de conhecimento do capitão. No romance, entretanto, sabemos que não só desde o primeiro encontro, quando Baltasar salva Afonso de ser executado, mas em todos os encontros entre os dois personagens, há forte tensão homoerótica, uma vez que ambos se impressionam com a beleza um do outro, assim como o simples toque, seja na mão, seja nas costas, é capaz de causar calafrios em ambos (BARROSO, 1940, p. 78). Podemos dizer, então, que há, no texto de Melo, uma tentativa de afastar qualquer possibilidade de se entender o desejo entre soldado e capitão como homoerótico, ao mesmo tempo em que há uma afirmação de uma mulheridade, ainda que não tradicional, de Baltasar/Maria Úrsula.

Dez anos depois, no ensaio A Senhora de Pangim (1942), motivado certamente pela edição portuguesa do romance (1940), Alfredo Pimenta procura não só discutir historicamente os feitos da personagem, mas busca principalmente fazer uma virulenta crítica à obra de Barroso. Entre os dois objetivos, prevalece, no entanto, uma crítica à infidelidade histórica do romance, ainda que Barroso (1932, p. 207) se preocupe em afirmar que a sua obra é um romance e não uma biografia, e por isso teria se utilizado da "fantasia" para narrar a personagem. A brecha que o autor português utiliza para questionar a veracidade histórica do romance são não só os relatos históricos que Barroso aponta como fontes utilizadas para compor a personagem (SOUZA SILVA, 1862; TEIXEIRA DE MELLO, 1881; RIO BRANCO, 1891), mas também a afirmação de Barroso de que teria copiado documentos

\footnotetext{
4 Após a publicação do romance $A$ Senhora de Pangim (1932) e antes da publicação da revista mexicana Mujeres Célebres (HARRELL, 1965), outros 15 textos históricos foram localizados, sendo três deles de autores portugueses, e 12 de autores brasileiros. Os relatos portugueses são "A Senhora de Pangim” (1942), de Alfredo Pimenta; “D. Maria Úrsula de Abreu e Lencastre” (1948), de Germano Correia; e "Uma heroína luso-brasileira na Índia portuguesa” (1965), de Augusto Cesar Castro Júnior. Os textos brasileiros são "A Senhora de Pangim” (1932), de Mario Melo; "Amboino" (1942), de Gustavo Barroso; "Maria Úrsula de Abreu Lancastre” (1943), de Fortunée Levy; "D. Maria de Lancastre” (1944), de Vivaldo Coaracy; "A mulher na história” (1948), de Gustavo Barroso; a efeméride de André Nilo Tadasco (1949), publicada no jornal $O$ Estado; "Uma heroína brasileira na Índia" (1949), de Gustavo Barroso; "Caminho de Goa” (1955), de Cecília Meireles; "O govêrno feminino duma capitania brasileira” (1958), de Gustavo Barroso; “Uma antepassada da donzela-guerreira” (1960), de Cecília Meireles; "muié macho, sim sinhô" (1962), de Nonnato Masson; e "Em Goa, uma heroína carioca” (1962), de Manuel Paulo Filho.
} 
em arquivos portugueses sobre Baltasar/Maria Úrsula, que seriam utilizados posteriormente para um estudo "não mais literário e sim absolutamente histórico" (PIMENTA, 1942, p. 186-187). Como resume Luiz Mário Costa (2016, p. 120), o intuito de Pimenta era provocar Barroso e desmerecer o suposto conteúdo histórico de seu romance.

O primeiro ponto questionado são as referências históricas utilizadas por Barroso, uma vez que as fontes brasileiras induziriam o romancista a cometer erros históricos e a supervalorizar a importância histórica de Baltasar/Maria Úrsula. Por isso, Pimenta desafia Barroso a mostrar as suas outras fontes, sob pena de considerar não só o romance como absolutamente inverossímil do ponto de vista histórico, "uma pitoresca história da carochinha" (PIMENTA, 1942, p. 187), mas também o seu autor um "falsário" (PIMENTA, 1942, p. 181). Apesar de ter voltado à história de Baltasar/Maria Úrsula em 1942, com a crônica "Amboino", Barroso só apresentou novas fontes históricas, assim como o estudo "absolutamente histórico", em 1949, com o ensaio "Uma heroína brasileira na Índia"s.

De acordo com Pimenta (1942, p. 180), o primeiro relato histórico conhecido sobre a personagem seria a obra do português Damião Froes Perim (1740), muito anterior, portanto, às fontes de Barroso, que datam da segunda metade do século XIX (SOUZA SILVA, 1862; TEIXEIRA DE MELLO, 1881; RIO BRANCO, 1891). Nesse mesmo sentido, de acordo com Pimenta (1942, p. 181-182), o primeiro documento régio a registrar a recompensa do rei $\mathrm{D}$. João $V$ à personagem seria de 14 de março de 1718 , e não o de 8 de março de 1718 descrito por Barroso (1932, p. 193). Além disso, um documento de 23 de março de 1720 não só remeteria aos documentos de 14 de março de 1718 e de 9 de março de 1720 , como também descreveria gratificações dadas a outros soldados, o que mostraria que Baltasar/ Maria Úrsula não teria recebido um prêmio muito diferente do que aqueles dados a outros soldados (PIMENTA, 1940, p. 185-186), retirando, portanto, a perspectiva de heroicidade e excepcionalidade da personagem.

No entanto, como mostramos em artigo anterior (MAIA, 2020), não só encontramos um outro relato histórico anterior àquele apontado por Pimenta (FROES PERIM, 1740), o texto publicado em 24 de março de 1718 no jornal português Gazeta de Lisboa, como também esta nova fonte confirma a existência da carta régia de 8 de março de 1718, ficcionalizada por Barroso (1932, p. 193). Infelizmente não conseguimos localizar os documentos régios, no entanto, ao contrário do que sugere Pimenta (1942, p. 181), o alvará não é uma invenção nem de Barroso e nem das fontes históricas brasileiras, uma vez que a nota do jornal Gazeta de Lisboa cita a resolução de 8 de março de 1718, que aparece na obra de Barroso, mas não cita o alvará de 14 de março de 1718 , que seria anterior à nota do jornal lisboeta, e é referência para Pimenta.

Assim, inverídica é a afirmação de Pimenta (1942, p. 7), de que Baltasar/Maria Úrsula teria gozado da mercê do Paço de Pangim por apenas três anos, e não a narração de Barroso (1932, p. 194), que diz que a personagem gozou da mercê por seis anos. Além disso, Pimenta (1942, p. 187) não se apoia em nenhum documento histórico para sugerir que não é crível que a personagem tenha vivido durante 14 anos como Baltasar, sem que fosse descoberta a "falsidade" do seu "disfarce", ao contrário de todos os documentos históricos que afirmam que a personagem viveu durante quase 14 anos como soldado, como narra Barroso (1932).

\footnotetext{
5 Os quatro relatos não ficcionais (1942, 1948, 1949, 1958), assim como as duas obras ficcionais de Barroso (1932, 1956), sobre Baltasar/Maria Úrsula serão analisados ao longo deste artigo.
} 
Assim como a maior parte dos autores portugueses, Pimenta não procura explicar as motivações da personagem para a transição de gênero e para a ida à guerra. No entanto, entende essa transição como disfarce e como pouco crível (PIMENTA, 1942, p. 187), Baltasar seria somente um "nome de empréstimo" (PIMENTA, 1942, p. 179). Da mesma forma, também não narra como a personagem viveu após dar baixa como soldado, mas, ao contrário da maior parte dos textos portugueses, assim como faz Froes Perim (1740), única fonte utilizada pelo autor, afirma o casamento de Baltasar/Maria Úrsula (PIMENTA, 1942, p. 179).

Nesse mesmo ano, em 1942, Gustavo Barroso publicou a crônica “Amboino”, na edição 173, do jornal fluminense A Manhã. No entanto, o texto não é ainda o estudo "absolutamente histórico" sobre a personagem prometido pelo autor (BARROSO, 1940, p. 9), apesar de apontar para informações coletadas em documentos na Torre do Tombo, assim como também não é uma resposta às críticas de Pimenta (1942). Escrito no contexto do movimento de independência da Índia, Barroso recupera a história de Baltasar/Maria Úrsula como uma forma de estabelecer um vínculo entre o Brasil e Goa, destacando assim a participação da personagem na tomada do forte de Amboino, no século XVIII.

O texto, no entanto, reafirma a mulheridade da personagem e entende a transição de gênero e a vida como soldado como uma "heroína em trajes de homem" que lutou nas guerras do Oriente (BARROSO, 1942, p. 4). A vida como soldado seria somente um disfarce e Baltasar seria apenas um pseudônimo. Se no romance é possível inferir certa ambiguidade na narração da transição de gênero, neste o autor nega mais abertamente a transição de gênero como uma possibilidade de compreensão de si. Assim, não só o casamento seria expressão dessa mulheridade, como também a manutenção dos trajes "varonis" e da espada após dar baixa como soldado desaparecem da narrativa. Além disso, confirmando a narrativa literária, Barroso afirma a fuga de um possível casamento forçado como a causa para a vida como homem e soldado.

Em 1943, nos Anais do Museu Histórico Nacional, Fortunée Levy publica uma série de biografias de importantes "heroínas brasileiras", que deixaram de lado "essa poderosa arma feminina, que é a meiguice", e "empunharam outras [armas] mais rudes e pesadas" (LEVY, 1943, p. 497). Ao contrário de Melo (1932), que entende ser a obra de Barroso (1932) um romance histórico, o que significa reescrever relatos históricos e preencher as lacunas históricas com "fantasia”, e ao contrário de Pimenta (1942), que entende que a obra deve ser exaustivamente fidedigna às fontes históricas, Levy (1943) toma o romance de Barroso como informação histórica. Informações romanceadas da obra de Barroso são transcritas por Levy como de fundo histórico, como podemos ver nas nomeações das naus onde teria embarcado Baltasar. Corrobora com essa leitura, o fato de a única fonte "histórica” indicada pelo texto biográfico ser o romance de Barroso (1932).

No que se refere ao gênero, Baltasar/Maria Úrsula é entendido como uma mulher, por isso prevalece a descrição da personagem no feminino, ainda que afirme que, para manter a lembrança de seus feitos de guerra, a personagem seguiu trajando roupas masculinas e espada. $\mathrm{O}$ autor, entretanto, não dá explicações sobre as motivações para a transição de gênero e para a vida como soldado. A leitura do texto possibilita uma interpretação contra os próprios interesses do autor, uma vez que, apesar da reafirmação da mulheridade, a descrição da manutenção da espada e do "trajo varonil" possibilita a leitor inferir dissonâncias entre o que o autor afirma e a realidade vivida por Baltasar/Maria Úrsula. Por fim, cabe destacar também que, ao contrário dos outros textos históricos e literários, Levy 
(1943, p. 510) afirma que a personagem casou logo após chegar em Goa, com o seu companheiro de viagem, o capitão Arrais de Melo, o que sugere, portanto, que a transição de gênero, se não era conhecida por todos, era pelo menos conhecida por Afonso.

No ano seguinte, em 1944, Vivaldo Coaracy publica a efeméride “D. Maria De Lancastre", no sexto volume do livro $O$ Rio de Janeiro no século dezessete. A presença da personagem em publicações de efemérides não é nova, e remete aos textos de Macedo (1876), Teixeira de Mello (1881) e do Barão de Rio Branco (1891). No entanto, enquanto nas três primeiras efemérides a personagem aparece narrada a partir do dia $1^{\circ}$ de setembro de 1700 , data que representa ao mesmo tempo o alistamento no exército colonial português e o reconhecimento oficial de sua identidade masculina, em Coaracy a personagem aparece ligada ao ano de 1682, data de seu nascimento e da designação de sua identidade feminina.

Se a data do alistamento militar nos outros textos permitia ao leitor algum reconhecimento da identidade masculina, a escolha da data do nascimento serve antes de tudo para reafirmar a mulheridade da personagem. Nessa perspectiva, o autor omite até mesmo o nome Baltasar do Couto Cardoso, resumindo toda a sua vida como soldado à afirmação de que viveu "disfarçada de homem" (COARACY, 1965, p. 208). Atribui, também, como causas para viver "disfarçada de homem" e para ir à guerra, seguindo a Macedo (1876), o "desespero de um amor contrariado". Reafirmando, assim, não só a mulheridade da personagem, mas também a sua dependência de uma figura amorosa masculina.

Além disso, o texto ainda diz que, após dar baixa como soldado, despiu o "disfarce", reassumiu "o papel feminino" e se casou com Arrais de Melo, o que parece sugerir que um novo amor, agora bem "resolvido", é capaz de recolocar Baltasar/Maria Úrsula dentro do binarismo e das normatividades de gênero. Todas as escolhas do autor, portanto, servem para reafirmar o feminino e negar a transição de gênero, seja pela data que escolhe para inscrevê-la no livro, seja pelo silêncio que impõe sobre o seu nome masculino, seja pela constante reafirmação da transição como disfarce, seja por resumir as principais decisões de sua vida à dependência amorosa, seja por afirmar que morreu conformada ao papel feminino tradicional.

Quatro anos depois, em Portugal, Germano Correia publica, em 1948, no livro História da colonização portuguesa na Índia, em seu volume V, o texto "D. Maria Úrsula de Abreu e Lencastre". Ao contrário do texto de Pimenta (1942), que questiona a verdade histórica do romance de Barroso (1940), o texto de Correia (1948) toma o romance de Barroso (1940) como verdade histórica, e, assim, transcreve trechos inteiros da obra como se fossem documentos históricos (CORREIA, 1948, p. 65). Da mesma forma, ao contrário da maior parte dos relatos portugueses, que não procuram explicar as motivações da personagem para a transição de gênero e para a vida como soldado, Correia (1948, p. 565 ) sugere que um "consórcio indesejado e projectado por imposição paterna" foi a causa para a fuga da casa paterna e o alistamento no exército colonial português.

A transição de gênero, no entanto, é entendida como um disfarce (CORREIA, 1948, p. 565), e assim como na maior parte das narrativas sobre "donzelas-guerreiras" é o ferimento em batalha, quando defendia Arrais de Melo, que faz com que seja conhecida a transição, entendida no texto como a descoberta do "verdadeiro sexo" (CORREIA, 1948, p. 568-569). Da mesma forma como nos relatos brasileiros, Correia cita o casamento com Arrais de Melo, em 1714, (CORREIA, 1948, p. 572) e diz que a personagem ficou conhecida em vários lugares do mundo português (CORREIA, 1948, p. 573), 
o que indica que a obra de Barroso (1940) inverte a lógica onde os textos portugueses eram lidos como fontes para os relatos brasileiros.

O texto, no entanto, apresenta duas inovações. Na primeira delas, sem informar sua fonte, afirma que Maria Úrsula/Baltasar e Arrais de Melo tiveram um filho chamado João, mesmo nome de seu pai e também do rei D. João V, que lhe concedeu a mercê do Paço de Pangim e uma pensão (CORREIA, 1948, p. 569). Esta informação, no entanto, não aparece em nenhum outro relato histórico ou literário. Uma segunda inovação diz respeito à possibilidade da personagem ter seguido combatendo mesmo após ser conhecida a transição de gênero, o que também pode ser inferido a partir do relato de Barroso (1949), uma vez que a "descoberta" da transição de gênero levaria a personagem, de acordo com os outros textos, a dar baixa como soldado.

Um despacho de 9 de setembro de 1713, do governo português em Goa, indica a cessão a "Dona Maria Úrsula de Abreu e Lencastre" "dois pedaços de palmares” de terra, na cidade de Chaul, que foram de Manuel Teixeira, falecido sem deixar descendentes ou herdeiros (CORREIA, 1948, p. 570-571). Outro documento do governo português em Goa, datado de 8 de março de 1718, no entanto, diz que Maria Úrsula/Baltasar deu baixa do serviço militar em 12 de maio de 1714, tendo casado no mesmo ano com Arrais de Melo, e recebendo como recompensa o usufruto do Paço de Pangim e a pensão de um xerafim por dia (CORREIA, 1948, p. 571-572). Esses dois documentos, portanto, indicam que, entre 9 de setembro de 1713 e 12 de março 1714, Maria Úrsula/Baltasar seguiu como soldado, mesmo após ser conhecida a transição de gênero.

Nesse mesmo ano, em 1948, Barroso publica, na edição 173 da revista mensal $A$ Cigarra, novo texto a retomar a história de Baltasar/Maria Úrsula, o ensaio "A mulher na história", onde o autor aponta para as mesmas fontes históricas do romance (SOUZA SILVA, 1862; TEIXEIRA DE MELLO, 1881; RIO BRANCO, 1891), mas fornece outras pistas sobre os documentos que teriam sido copiados nos “arquivos portugueses”. Sem especificar a quais documentos se refere, diz que os teria copiado dos "Papéis da Índia” na “Torre do Tombo, em Lisboa”, e as cópias estariam guardadas nos arquivos do Museu Histórico Nacional brasileiro. Esses textos, infelizmente, ainda não são conhecidos.

Exceto por essas novas informações sobre os “arquivos portugueses”, e pela afirmação de que seu pai era um grande fazendeiro no Rio de Janeiro, não há novos dados sobre a personagem. Barroso ainda afirma que Baltasar/Maria Úrsula é a mais importante personagem feminina da história brasileira, apesar de pouco conhecida. Em diálogo não explicitado com Melo (1932), diz que o soldado e o capitão se apaixonaram durante as campanhas militares, e não durante a convalescência. Por fim, de modo geral, Barroso (1948) reafirma a mulheridade da personagem, o casamento, e, apesar de afirmar que faleceu "cercada do respeito geral", nada fala sobre o uso de roupas entendidas como masculinas após dar baixa como soldado. O texto traz ainda uma gravura sobre Baltasar/Maria Úrsula, sobre a qual falaremos no próximo ponto, além de informar que o romance está em sua terceira edição.

Em $1^{\circ}$ de setembro de 1949, André Nilo Tadasco, no jornal O Estado, de Florianópolis, em sua edição 10.565 , na coluna "Hoje no passado", publica nova efeméride sobre a personagem 6 . No entanto, ao contrário de Coaracy (1944), Tadasco escolhe novamente a data do reconhecimento estatal da masculinidade para falar de Baltazar/Maria Úrsula. Além disso, apesar de ser uma nota muito breve,

6 Essa mesma efeméride, com pequenas alterações, foi publicada em $O$ Estado nos dias $1^{\circ}$ de setembro de 1951 , na edição 11.223 , e $1^{\circ}$ de setembro de 1953, na edição 11.695 . 
onde consta apenas o local de nascimento e o ano que assentou praça em Lisboa como soldado, o autor não deixa de afirmar o nome Baltazar do Couto Cardoso, ainda que o entenda como um nome falso. Nesse sentido, mesmo que pareça sugerir a transição como uma impossibilidade, permite ao leitor brechas para ler a transição de gênero de outra forma.

Nesse mesmo ano, em 3 de dezembro de 1949, na revista O Cruzeiro, Gustavo Barroso finalmente publica, sete anos depois das virulentas críticas de Alfredo Pimenta (1942) e 17 após a publicação do seu romance (1932), o prometido estudo "absolutamente histórico" sobre Baltasar/Maria Úrsula, o ensaio "Uma heroína brasileira na Índia”. Nesse estudo, Barroso (1949, p. 54) informa que o romance foi escrito a partir dos relatos de Souza Silva (1862), Teixeira de Mello (1881), Rio Branco (1891), mas, em relação ao Prefácio do romance e ao artigo anterior (1948), acrescenta uma nova fonte, um texto, não localizado, publicado na revista luso-goesa O Oriente Português, de 1905, do goês José António Ismael Gracias?. Foi somente após a publicação da edição portuguesa do romance que, em 1940, o autor fez uma "acurada busca nos Arquivos Portugueses", especificamente na Torre do Tombo e na Biblioteca Nacional de Lisboa, cujos resultados serviram para reafirmar as suas escolhas narrativas e históricas, mas também trouxeram novas informações sobre Baltasar/Maria Úrsula que não haviam sido incorporadas ao romance, que já se encontrava publicado no Brasil (1932) e em Portugal (1940).

Barroso apresenta, então, as principais informações copiadas de seis textos da Torre do Tombo e de dois da Biblioteca Nacional, além de trazer citações desses arquivos e mapas da cidade de Goa. Esses novos documentos apresentam não só informações biográficas sobre Arrais de Melo, que seria natural de Villa Real, mas também afirmam que tanto o capitão quanto o soldado chegaram à Índia juntos na moção de 1700. Afirmam também que Baltasar/Maria Úrsula, além da mercê do Paço de Pangim e da pensão de um xerafim, também teria recebido "dois pedaços de Palmares" na cidade de Chaul (BARROSO, 1949, p. 36). Essas informações constam também em História de Goa: política e arqueológica (1898), do padre luso-goês Manoel Gabriel de Saldanha, e em História da colonização portuguesa na Índia (1948), do português Germano Correia. No entanto, enquanto Saldanha (1990, p. 190) sugere que a única recompensa foram "os dois pedaços de palmares" em Chaul, Barroso (1949, p. 54) e Correia (1948, p. 570-571) sugerem que as terras recebidas em Chaul foram entregues após requerimento de recompensa realizado em 1713, enquanto a pensão e a mercê do paço de Pangim foram recebidas após a personagem dar baixa como soldado em março de 1714, o que nos permite inferir que a personagem seguiu como soldado mesmo após ser conhecida a transição de gênero.

Os documentos também detalham o nome de todas as campanhas que Baltasar/Maria Úrsula participou, além do nome de todos os capitães aos quais esteve subordinado, o que inclui Afonso Teixeira Arrais de Melo (BARROSO, 1949, p. 36). O texto ainda afirma que a personagem faleceu cercada do respeito e da admiração daqueles que a conheceram. No que se refere ao seu gênero, apesar das palavras-chave colocadas abaixo do título do ensaio, que se referem a uma "mulher-soldado", e apesar de todos os documentos afirmarem a vida como soldado, Barroso em seu texto refere-se à personagem sempre como uma mulher, ao contrário do seu romance (1932), e, agora, afirma que o nome Baltasar do Couto Cardoso era apenas um pseudônimo (BARROSO, 1949, p. 32). Podemos destacar que há no romance, em relação ao ensaio "absolutamente histórico", uma visão menos normativa sobre gênero.

\footnotetext{
7 A informação de Barroso é imprecisa. Consulta à coleção digitalizada da revista goesa não encontrou a referência do artigo de Gracias. Memória da África e do Oriente - Coleção O Oriente Português. http://memoria-africa.ua.pt/Library/OOP.aspx
} 
Por fim, Barroso, assim como no romance, sugere o "desespero dum amor contrariado" como causa para a fuga da casa paterna e a vida como homem e soldado (BARROSO, 1949, p. 32).

Seis anos depois, em $1^{\circ}$ de maio de 1955, Cecilia Meireles publica a crônica "Caminho de Goa", no Suplemento Literário do Diário de Notícias. Em seguida, no dia 23 de julho de 1955, o mesmo texto é publicado no Correio do Povo. Na crônica, Meireles descreve a viagem de barco de Bombaim a Goa, a convite da "amável" autoridade portuguesa, e nesse percurso faz também uma viagem pelas memórias, personagens e costumes que identifica e imagina como próprios da cidade de Goa. Assim, aborda, por exemplo, a musicalidade toponímica da região, os idiomas falados, as roupas e alimentos típicos, bem como as vidas de São Francisco Xavier, Afonso de Albuquerque, Manuel Maria du Bocage e Baltazar/Maria Úrsula.

Nossa personagem aparece, portanto, junto a outras pessoas que compõem o imaginário de Meireles sobre a região. No entanto, as informações são breves, uma vez que o texto limita-se a informar o local de nascimento e o local onde viveu "vestida de homem”. Nessa brevidade, Meireles não fala sobre os quase 14 anos que a personagem viveu e foi reconhecida, inclusive pelo estado português, como o soldado Baltasar, ao contrário, reduz toda essa complexa experiência a estar "vestida de homem”. Da mesma forma, não há informações sobre as batalhas que participou, sobre a recompensa régia que recebeu ou sobre como viveu após dar baixa como soldado.

A grande novidade do texto é, no entanto, o paralelo que a poetisa estabelece entre o romance ibérico A donzela que foi à guerra e Baltazar/Maria Úrsula, ao sugerir que a vida deste foi como a do romanceiro da "donzela-guerreira”. Meireles é, provavelmente, a primeira a ler Baltazar/Maria Úrsula a partir da tradição da crítica literária portuguesa e brasileira sobre as donzelas-guerreiras. No entanto, assim como os outros textos críticos, mais sugere essa possibilidade de leitura do que realmente faz um exercício analítico a partir dessa perspectiva.

Em 1958, dois anos após a publicação da história em quadrinhos sobre Baltasar/Maria Úrsula (BARROSO, MONTEIRO, 1956), Gustavo Barroso publica, na edição 34 da revista O Cruzeiro, novo texto a abordar a personagem, o ensaio "O govêrno feminino duma capitania brasileira". Nele, Barroso afirma que o estudo do papel da mulher na colonização, não só o "trabalho doméstico da manutenção do lar e da criação da prole, mas também no domínio social e político”, ainda está por ser feito (BARROSO, 1958, p. 77). Por conta disso, o texto, que parece sugerir uma continuidade futura, apresenta-se como uma tentativa de biografar a vida de uma mulher importante para a colonização do Brasil, D. Luíza Grimaldi, que governou durante quatro anos a capitania do Espírito Santo.

Assim, a partir de uma leitura que a entende exclusivamente como mulher, e que omite a transição de gênero e a vida como o soldado Baltasar, apesar de destacar "a atividade guerreira de que deu alta prova”, Baltasar/Maria Úrsula aparece como exemplo de outras mulheres que tiveram um papel destacado na colonização brasileira, como D. Brites, D. Leonor Teles e D. Luíza Grimaldi. Esse novo texto nada acrescenta sobre Baltasar/Maria Úrsula, servindo antes de tudo à reafirmação de sua mulheridade e à negação da transição de gênero, ao contrário das obras ficcionais do autor. A "fantasia" das obras ficcionais permite a Barroso a produção de certa dubiedade sobre o gênero da personagem, algo que os textos históricos parecem não permitir.

Dois anos depois, no ensaio "Uma antepassada da donzela guerreira”, publicado primeiro no livro Estudos e ensaios folclóricos em homenagem a Renato Almeida, em 1960, e depois na Revista Brasileira de 
Folclore, em 1964, Meireles volta não só ao tema da donzela-guerreira, mas também a Baltazar/Maria Úrsula, em um texto de grande força crítica. O ensaio trata também de Louise Labé, Catalina de Erauso, Antonia Rodrigues e Maria Quitéria, ainda que a antepassada a que se refere o texto seja Mu-lan ou Mook-lan. É importante dizer que em nenhum momento o ensaio menciona os nomes masculinos adotados pelas personagens históricas.

Meireles apresenta os diferentes títulos recebidos pelo romance A Donzela Guerreira, além de chamar atenção para donzelas-guerreiras históricas que são posteriores ao romanceiro ibérico. Baltazar/ Maria Úrsula é convocado ao texto como exemplo de uma donzela-guerreira brasileira, assim como Maria Quitéria. Além das informações dos locais de nascimento e lutas (como soldado), Meireles também trata do casamento da personagem aos 31 anos. Ainda que a experiência como soldado não seja resumida a "vestir-se como homem", como no texto anterior (MEIRELES, 1955), o casamento mais uma vez parece reafirmar a mulheridade da personagem.

Além disso, de forma semelhante a Souza Silva (1841), Meireles explica as motivações da personagem a partir da afirmação de que se tratava de uma "mulher" de "espírito inquieto e aventuroso, com temperamento ávido de sensações e grandes disposições para a bravura” (MEIRELES, 1964, p. 53). Por fim, aborda aquela que seria a mais antiga donzela-guerreira conhecida, a "heroína chinesa" Mu-lan, além de apresentar uma tradução, a partir do francês, da ainda pouco conhecida balada chinesa Mook-lan. Ainda que não se refira diretamente a Baltazar/Maria Úrsula, mas às donzelas-guerreiras em geral, Meireles destaca não só o "retorno" à feminilidade, mas também reafirma que a vida como homem é um "disfarce” (MEIRELES, 1964, p. 57).

Dois anos depois, motivado pela reconquista indiana de Goa, Manuel Paulo Filho publica, em 13 de janeiro de 1962, no jornal Correio da Manhã, o ensaio "Em Goa, uma heroína carioca”, onde aborda a vida de "uma importante heroína nacional", que lutou por Portugal em Goa. O texto também faz uma associação de Baltasar/Maria Úrsula com outras "heroínas nacionais", como Maria Quitéria, Joana Angélica, Benta Pereira, Anita Garibaldi, Ana Neri e outras, e utiliza, como principais fontes, as notas do professor Sylvio Salema, diretor do Instituo Histórico-Geográfico Brasileiro, que naquele momento estava preparando uma série de perfis biográficos de "heroínas nacionais”, além das informações biográficas romanceadas e produzidas pela baiana Ignez Sabino (1899).

Assim, o texto diz que Baltasar/Maria Úrsula, aos 18 anos cortou os cabelos e "vestindo-se à masculina" fugiu para Portugal. Apesar do corte de cabelo ser uma ação recorrente nas histórias sobre donzelas-guerreiras, uma vez que faz parte das ações relacionadas à transição de gênero, é a primeira vez que um texto aponta para esta ação ao se referir a Baltasar/Maria Úrsula. Ainda assim, a transição de gênero é sempre entendida como um disfarce, e, por isso, refere-se à personagem sempre no feminino. Nessa mesma perspectiva, a nova transição vivida por Baltasar/Maria Úrsula, após dar baixa como soldado, é entendida como um retorno "aos trajes de seu sexo".

Paulo Filho também afirma que foi o amor por um outro soldado o que teria levado Baltasar/ Maria Úrsula a dar baixa, mas além disso também diz que a personagem reconhece no casamento e na vida como esposa "o mais belo sonho de uma mulher". O amor é, portanto, uma força capaz de fazer a personagem retornar à ordem de gênero. $\mathrm{O}$ autor também nega, e diz que não passa de uma lenda, a afirmação de que um "ardente amor contrariado" seria a causa para a primeira transição e para a vida como soldado. Seguindo Sabino (1899), afirma que Baltasar/Maria Úrsula, desde a infância, esteve 
inclinado para a vida no quartel e para as roupas masculinas, e assegura que este sempre se entendeu como soldado e não como mulher.

Nessa explicação, ao mesmo tempo em que afasta a patologização e a psiquiatrização de Sabino (1899, p. 89), ao descrever a infância da personagem, uma vez que esta entende a transição como uma “verdadeira aberração da natureza”, Paulo Filho também sugere que o amor não pode ser causa para uma transição de gênero, ainda que possa ser causa para o retorno à ordem de gênero. $\mathrm{O}$ amor é antes ordem do que desvio, norma do que transgressão. Por fim, o autor também diz que a personagem teve filhos, criados e educados exemplarmente no Paço de Pangim.

Nesse mesmo ano, em 9 de maio de 1962, na edição 105, do Jornal do Brasil, aparece mais um texto a associar a figura de Baltasar/Maria Úrsula à de outras "muié macho" guerreiras da história do Brasil. O texto de Nonnato Masson faz uma extensa lista dessas mulheres e apresenta uma breve biografia sobre cada uma delas, como Abigail Pereira Nunes, Anita Garibaldi, Maria Quitéria, Benta Pereira, Clara Camarão, Maria Curupaiti, Chica Biriba, Maria Ortiz, Maria Déia, Rosa Maria de Siqueira e outras. Sobre Baltasar/Maria Úrsula, que é lida como uma dessas mulheres guerreiras, cuja transição de gênero é reduzida à afirmação de que viveu "vestida de homem”, o texto não só reafirma um amor mal resolvido como a causa para a transição e para a vida como soldado, como também inova ao sugerir que "Baltasar" seria o nome desse primeiro amor contrariado da personagem.

No entanto, o texto de Masson aponta, como fonte histórica de suas informações, a obra de Souza Silva, sem especificar a qual texto se refere. Como sabemos, Souza Silva aponta a índole belicosa, o coração varonil e o desejo de glória, como causas para a transição de gênero e para vida como soldado, por isso, o texto de Masson está mais próximo da efeméride de Macedo (1876), que aponta um "ardente amor contrariado" como motivação para a transição de gênero e para a vida como guerreiro. Além disso, Masson também demonstra ter feito uma leitura apressada da obra de Souza Silva, quando afirma que Baltasar/Maria Ursula teria recebido a condecoração da “Ordem Serafim da Índia”, enquanto o texto de Souza Silva fala em verdade em uma pensão de um xerafim pago na alfândega de Goa. Por fim, não há informações nem sobre como viveu após dar baixa como soldado, nem sobre um possível casamento.

Em 1965, o português Augusto Cesar Castro Júnior publica, nas atas do V Colóquio Internacional de Estudos Luso-Brasileiros, o artigo "Uma heroína luso-brasileira na Índia portuguesa”, último texto encontrado antes da publicação da revista mexicana Mujeres Célebres. Aparentemente alinhado à perspectiva lusotropicalista, vigente no colonialismo português desde 1954, o autor destaca o caráter multirracial da sociedade lusa e da brasileira, e entende que a história dos dois países, assim como dos "territórios ultramarinos", deve ser pensada conjuntamente, uma vez que vários personagens se destacaram em Portugal, no Brasil e na África Portuguesa. Após apontar para algumas figuras masculinas importantes para os três espaços territoriais, como Salvador Correia de Sá, destaca algumas mulheres de “inigualável heroísmo” como Clara Camarão, Isabel Fernandes, Maria Úrsula de Abreu Lencastre/ Baltasar e outras (CASTRO JÚNIOR, 1965, p. 6).

$\mathrm{O}$ autor entende, desde o início, a personagem como uma mulher (cisgênera), omitindo inclusive o seu nome masculino, assim como entende a transição de gênero como um disfarce (CASTRO JÚNIOR, 1965, p. 9). Maria Úrsula/Baltasar, portanto, seria um "modelo feminino de heroísmo e de ínclito amor da Pátria” (CASTRO JÚNIOR, 1965, p. 10). O texto, repete a maior parte dos outros relatos sobre a personagem, no entanto, duas questões precisam ser destacadas. Na primeira delas, 
contrariando a maior parte dos relatos portugueses, que não se propõe a explicar as motivações para a transição de gênero e para a guerra, assim como as três versões dos relatos brasileiros (SOUZA SILVA, 1841; MACEDO, 1876; SABINO, 1899), o autor propõe uma nova interpretação para as escolhas de Maria Úrsula/Baltasar. As decisões da personagem, para a transição de gênero e para a ida à guerra, seriam motivadas por um arrebatamento causado pela "leitura de romances de cavalarias e narrativas de feitos de Cruzadas” (CASTRO JÚNIOR, 1965, p. 9). Essa versão quixotesca, no entanto, não só não encontra nenhuma base histórica anterior, como também parece não produzir efeito posterior nas narrativas sobre a personagem.

Uma outra questão que precisa ser destacada se refere à possibilidade de a personagem ter vivido como soldado mesmo após ser conhecida a transição de gênero, o que também pode ser inferido em Correia (1948, p. 570-572) e Barroso (1949, p. 54). Essa leitura, no entanto, não aparece nos textos literários, e é minoritária nos relatos históricos, uma vez que a maior parte deles afirma que, após ser conhecido a transição de gênero, a personagem imediatamente dá baixa do exército colonial. Castro Júnior, no entanto, não apresenta fontes históricas para essa afirmação, ao contrário de Correia (1948) e Barroso (1949), que destacam documentos oficiais que a reconhecem como mulher em setembro de 1713, e que confirmam que o desligamento do exército em março de 1714. A afirmação de Castro Júnior parece antes indicar uma nova tendência de leitura sobre a personagem, que precisa ser verificada nos textos produzidos a partir de 1965, do que uma realidade histórica.

\section{PRIMEIRAS IMAGENS DA SENHORA DE PANGIM}

Antes das publicações das duas revistas em quadrinhos que narram e ficcionalizam a vida de Baltasar/Maria Úrsula, a Edição Maravilhosa, n. 116, de 1956, e a Mujeres Célebres, n. 57, de 1965, sobre as quais falaremos no próximo ponto, outros quadrinistas também se arriscaram a produzir imagens sobre a personagem. A primeira representação gráfica encontrada sobre Baltasar/Maria Úrsula foi produzida pelo pintor e ilustrador Armando Pacheco e outra por um autor desconhecido ${ }^{8}$.

Publicada em 29 de junho de 1941, na edição 10.533, do jornal $A$ Noite, a gravura de Pacheco sobre Baltasar/Maria Úrsula está dentro de um quadro onde aparecem fatos curiosos sobre personalidades brasileiras (Figura 1). A imagem representa a figura histórica, enquanto o texto detalha uma curiosidade relacionada àquela pessoa. Sobre Oswaldo Cruz, por exemplo, o texto diz que ele não usava o seu nome de registro em documentos oficiais, assinando sempre como "Gonçalves Cruz"; enquanto sobre José do Patrocínio e José de Alencar, o texto informa que os dois eram filhos de padres. As outras personagens destacadas são Felisberto Caldeira Brant, Dom Antônio de Mariz, D. Pedro II e D. Maria Ursúla de Abreu Lancastre.

A nossa personagem, portanto, aparece ao lado de outras seis figuras masculinas reconhecidamente importantes para a história do Brasil, o que significa um fato novo no seu imaginário, uma vez que as narrativas em torno de Baltasar/Maria Úrsula, quando acompanhadas de outras figuras históricas, está

8 Ao longo dessa investigação, obtivemos a notícia de que o Almanaque de O Lobinho, em sua edição de 1942, traria uma imagem, na página 8, da Senhora de Pangim, de autoria de Adolfo Aizen. O exemplar da revista, infelizmente, apesar dos muitos esforços de pesquisa, não foi localizado. Registramos que a Gibiteca do Centro Cultural São Paulo, único acervo público inteiramente dedicado aos quadrinhos, localizado na cidade de São Paulo (Brasil), esteve encerrado por todo ano de 2020 e nos primeiros meses de 2021 por força da pandemia de COVID 19. 
sempre, como vimos, mediada por figuras femininas. No entanto, enquanto o desenho de Pacheco retrata uma figura masculina empunhando uma espada, o texto reafirma a mulheridade da personagem, não só porque diz que "Maria Ursúla de Abreu Lancastre foi a primeira mulher-soldado do Brasil", mas também porque omite o seu nome masculino, assim como reafirma o seu casamento.

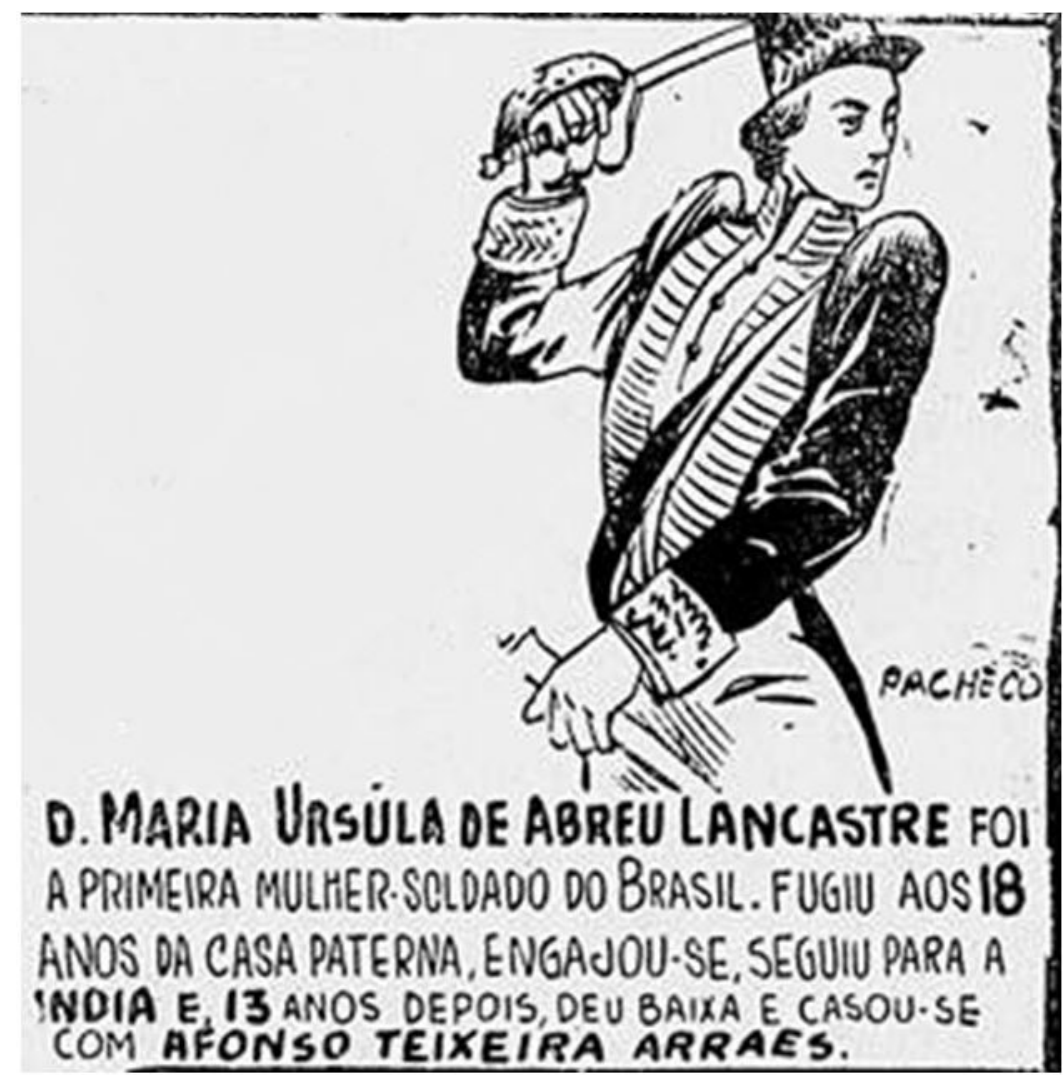

Figura 1 - A Noite, Edição 10.533, 1941, p. 3.

A ilustração, ao retratar uma evidente figura masculina, contra o próprio texto escrito, cumpre a importante função de afirmar aquilo que é negado pelas palavras, a masculinidade e a identidade masculina de Baltasar/Maria Úrsula, o que justifica inclusive a sua presença no quadro com outras importantes figuras masculinas. Da mesma forma, podemos dizer que a contradição entre a imagem e o texto escrito cumpre também a função de problematizar as normas de gênero e a própria masculinidade, uma vez que torna visualmente possível não só a transição de gênero específica da personagem, mas também a transição de gênero de forma geral.

Publicada em novembro de 1948, na edição 173, da revista A Cigarra, junto com o ensaio "A Mulher na história”, de Gustavo Barroso, onde o autor retoma a história de Baltasar/Maria Úrsula reafirmando a sua mulheridade e heroicidade, a gravura, de autoria desconhecida, ocupa uma página inteira da revista e reconstrói tanto a identidade feminina quanto a identidade masculina da personagem (Figura 2). De forma geral, podemos dizer que, ao contrário da dissonância entre o texto visual e o texto escrito de Pacheco (1941), a gravura agora parece confirmar aquilo que é narrado pelo texto de Barroso. 


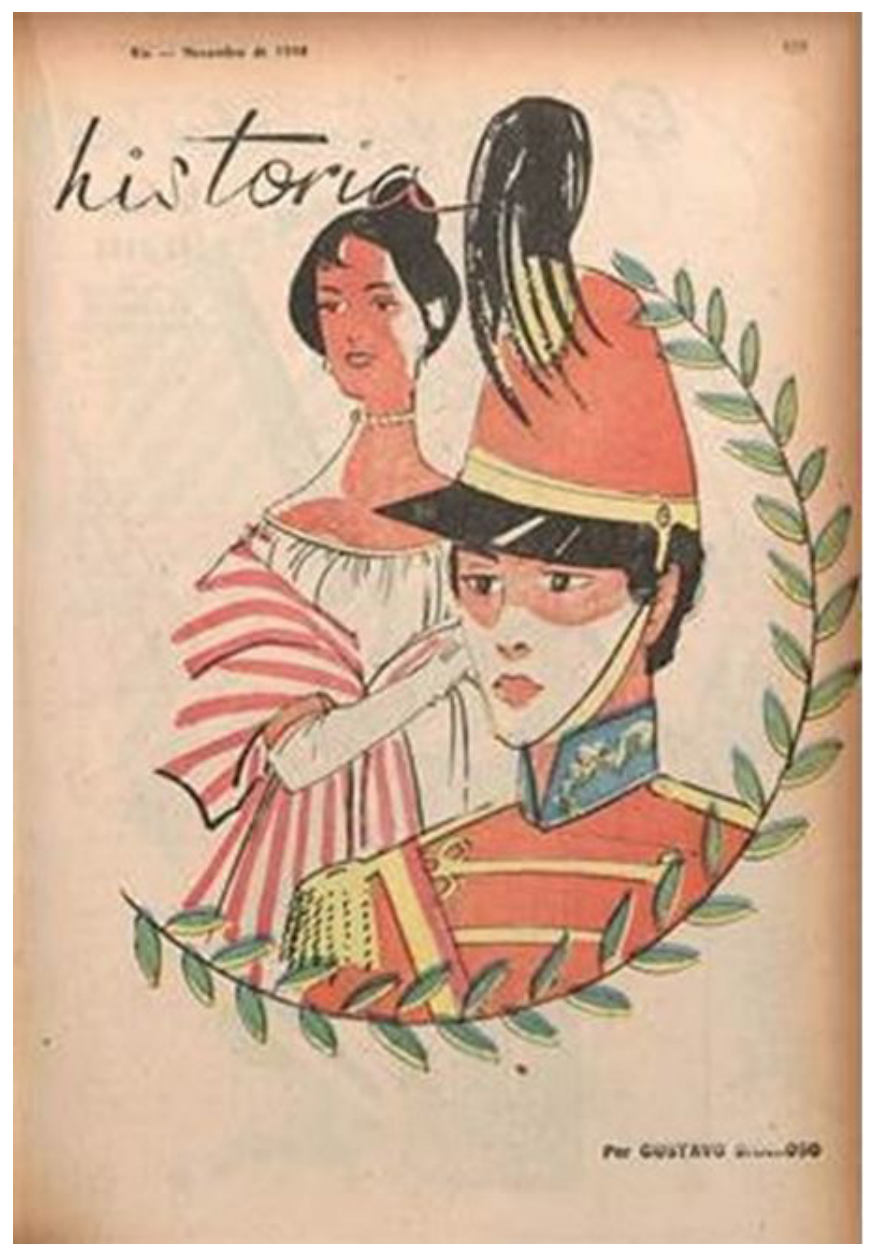

Figura 2 - A Cigarra, Edição 173, 1948, p. 109.

Se entendermos que a imagem feminina construída para Maria Úrsula se refere antes a uma jovem mulher do que a uma adolescente, podemos dizer que a imagem reconstrói a personagem após dar baixa como soldado, o que significaria, portanto, uma transição à uma feminilidade bastante tradicional, seja pela indumentária recatada e aristocrática, seja pela sugerida gestualidade da personagem representada, ao mesmo tempo em que há também uma negação da manutenção dos trajes varonis e da espada. Esta perspectiva, como vimos, aparece também no texto escrito, uma vez que Barroso aponta para o casamento, mas nada fala nem sobre o uso de roupas entendidas como masculinas nem sobre a manutenção da espada após a personagem dar baixa como soldado. A colocação da figura feminina por trás da figura masculina parece também indicar que por trás do soldado Baltasar esteve sempre a figura de Maria Úrsula.

No que se refere à imagem masculina, a gravura apresenta a figura de um jovem soldado não em ação, mas em supostos trajes de gala. Não há uma sugestão de virilidade, nem de valentia, nem de bravura ou de heroicidade, nem da excepcional capacidade guerreira da personagem. A imagem, portanto, sugere um personagem mais afeito aos salões da aristocracia do que um soldado que se notabilizou pela sua atuação em guerra. Apesar disso, a justaposição das duas figuras sugere, à revelia do texto escrito por Barroso, a artificialidade das normatividades de gênero, uma vez que as duas figuras reunidas e quase sobrepostas sublinham a transição de gênero de Baltasar/Maria Úrsula. 
De forma geral, podemos dizer que essas primeiras imagens gráficas de Baltasar/Maria Úrsula servem, principalmente, seja por contradição, seja por escaparem da perspectiva ideológica dos textos escritos, tanto à reafirmação da masculinidade e da identidade masculina quanto da transição de gênero da personagem. As imagens, portanto, mesmo quando construídas para complementarem o sentido do texto escrito, produzem dissonâncias e permitem perceber um não alinhamento à normatividade sobre masculinidade ao sublinharem o processo de transição de gênero vivido e experimentado pela personagem.

\section{A SENHORA DE PANGIM, EDIÇÃO MARAVILHOSA}

A Senhora de Pangim: romance histórico de Gustavo Barroso foi publicado em janeiro de 1956, em edição extra da revista em quadrinhos mensal Edição Maravilhosa, n.116, com desenhos de Gutenberg Monteiro e textos de Gustavo Barroso. De acordo com as informações da contracapa, as revistas publicadas pela editora Brasil-América visavam não só extasiar os leitores com a história do Brasil, mas também moralizar as histórias em quadrinhos. A informação "Para Adultos”, que consta na capa, procura manter as "transgressões" de gênero da personagem distante de crianças e adolescentes, ao mesmo tempo em que destaca para os adultos o caráter controverso deste romance histórico em quadrinhos.

A capa, como podemos ver na Figura 3, recria uma cena, presente em quase todas as narrativas históricas, a tomada de um forte, provavelmente o de Amboino. Nesta, não só podemos ver Baltasar entrando sozinho e à frente de todos na fortaleza, empunhando uma espada e uma bandeira portuguesa, como também podemos ver ao fundo da imagem um oficial, cujas roupas indicam pertencer à alta patente do exército português, que parece comandar a ação e também celebrar a entrada de Baltasar no forte. Entre o capitão que comanda e celebra a ação e Baltasar que avança sozinho sobre o forte, a massa anônima e sem rosto de soldados luta pela posse da fortaleza. Desde a capa, portanto, podemos ver que o guerreiro centralizado e destacado pela imagem não só se diferencia da massa dos outros soldados, como também ofusca os seus comandantes.

A imagem da capa também nos apresenta um guerreiro elegantemente vestido e de aparência excessivamente jovem. O leitor que desconhece a história que será narrada provavelmente entenderá, pela capa, que o herói é um adolescente. No entanto, a primeira imagem de Baltasar, após a capa, aproxima-o de uma imagem mais andrógina, o que certamente provoca e perturba a perspectiva cisgênera dos leitores (Figura 4). Nesta página, como podemos ver a seguir, aparecem os rostos das quatro personagens principais, além de breve fragmento escrito de Barroso. No entanto, o texto, contradizendo o indicado pelo prefácio do romance, onde o autor afirmou se tratar de romance e não de biografia, e por isso teria se utilizado da "fantasia" (BARROSO, 1940, p. 9), como se também respondesse e provocasse Pimenta (1942), destaca, ao contrário, que nos quadrinhos há pouco espaço para a "fantasia" dos autores, reafirmando, portanto, o caráter de verdade histórica da obra. 


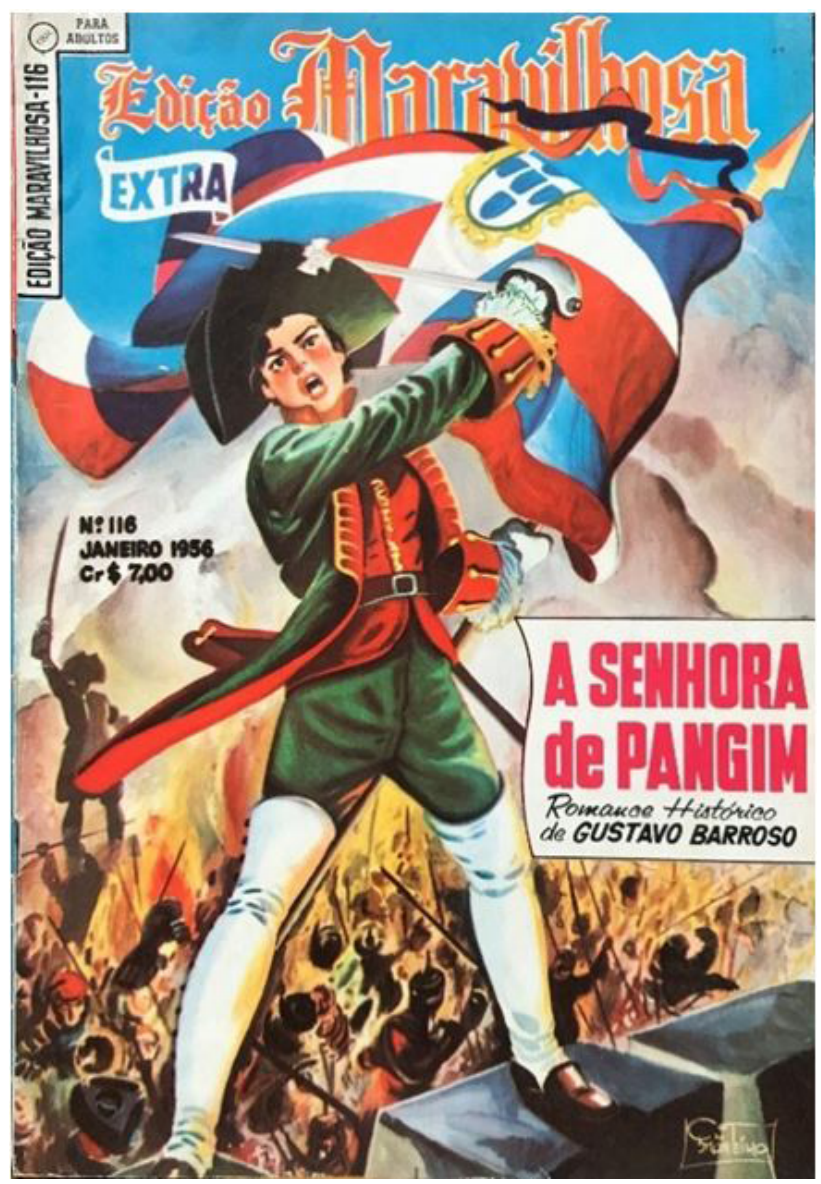

Figura 3 - Edição Maravilhosa, n. 116, 1956, capa.

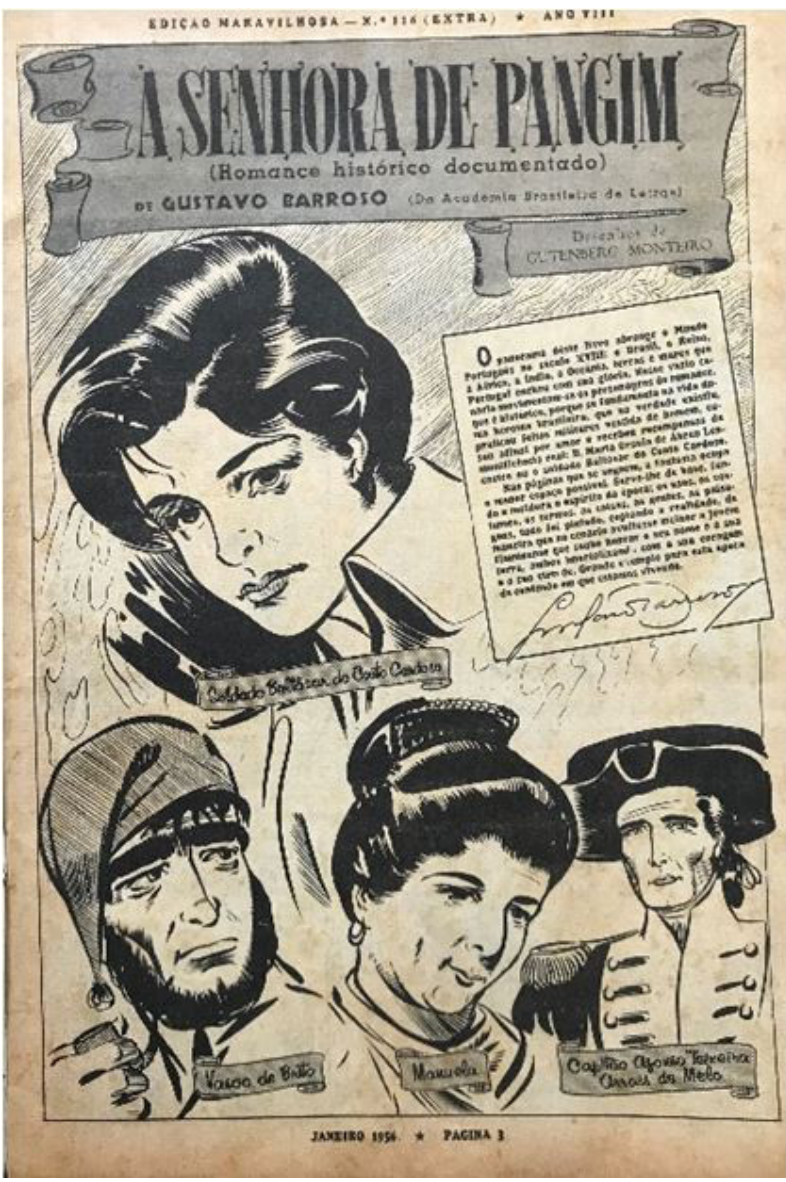

Figura 4 - Edição Maravilhosa, n. 116, 1956, p. 3.

Sobre a relação entre texto escrito e texto visual, podemos dizer que há um uso excessivo de palavras, uma vez que não só quase todos os quadros possuem longos textos, como há também quadros que dispensam completamente o uso de imagens, como podemos ver na Figura 5. Os desenhos em sua grande maioria servem unicamente para materializar o que está descrito no texto, normalmente sem trazer qualquer informação nova à narrativa. Podemos dizer que o texto escrito por Barroso, copiado quase integralmente de seu livro homônimo, não só se sobrepõe às imagens de Monteiro, como também as tornam dispensáveis.

Há no romance um jogo dúbio sobre a transição de gênero que também se repete nos quadrinhos. Enquanto no romance há uma constante sugestão, através do canto do jovem soldado, de que há algo de feminino em Baltasar, nos quadrinhos essa sugestão é simplesmente suprimida do texto. No entanto, enquanto no romance há pequenos trechos que apenas sugerem ser a transição conhecida por Manuela, amiga que acompanha Baltasar à Índia e vive com ele até o final de sua vida, nos quadrinhos esse possível conhecimento é explicitado pelo texto. Dessa forma, ainda que a transição de gênero da personagem seja desconhecida, as duas narrativas fornecem, ao longo da obra, elementos para que o leitor não seja surpreendido, ao final do texto, pela "confissão" de Baltasar. 


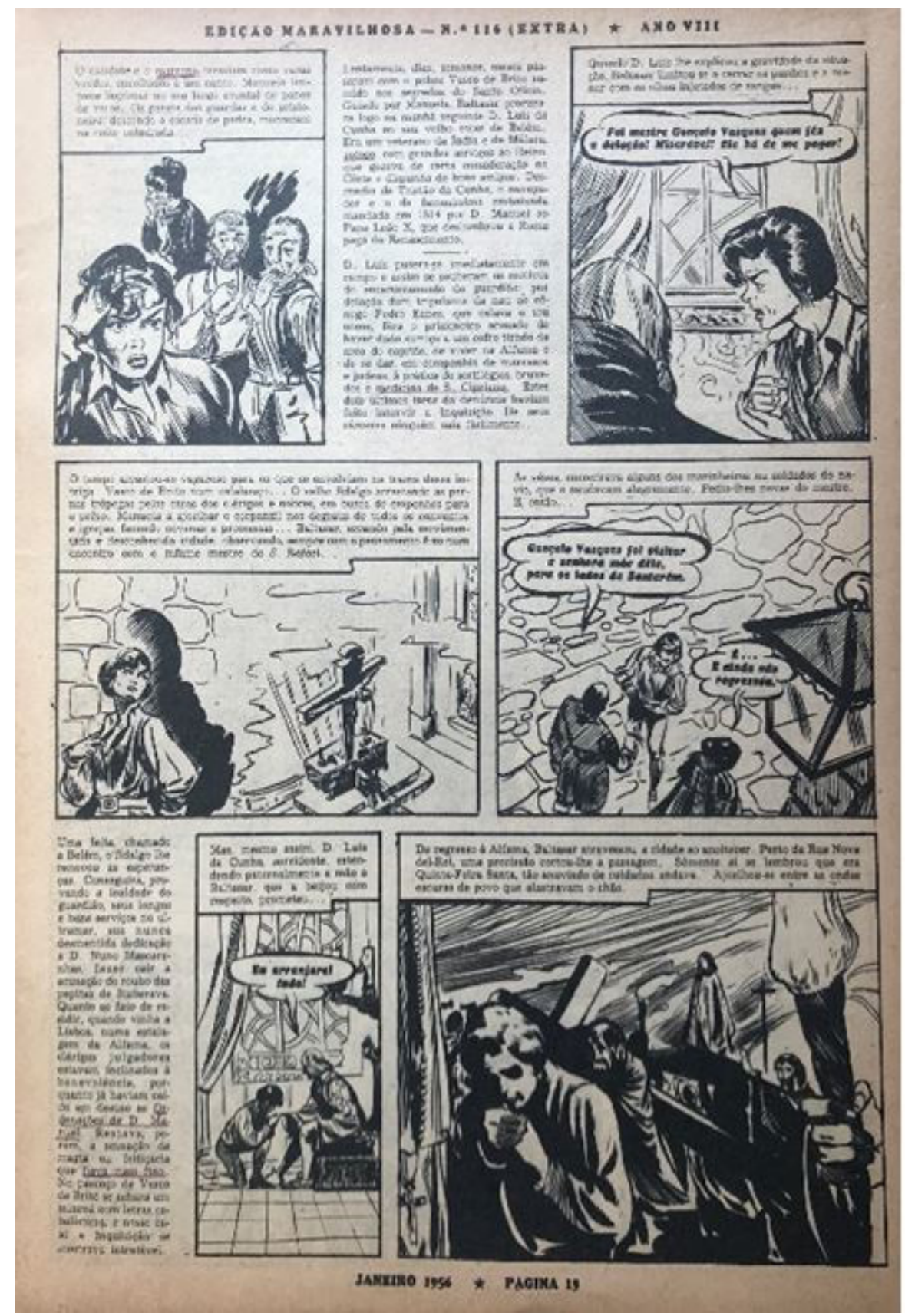

Figura 5 - Edição Maravilhosa, n. 116, 1956, p. 19.

Assim como a maior parte das narrativas sobre "donzelas-guerreiras", apesar dos temores e das reações violentas de Baltasar em relação ao não reconhecimento de sua masculinidade (BARROSO; MONTEIRO, 1956, p. 34-35), a transição de gênero não só é desconhecida, como a masculinidade de Baltasar é reafirmada pela maior parte das personagens. $O$ desejo que o soldado provoca, por sua força e beleza, em mulheres, é também parte do reconhecimento público de sua masculinidade, e, nem mesmo a negativa diante do assédio feminino é entendida como falta de masculinidade, uma vez que é equiparado ao mítico rei D. Sebastião I, o que significaria ser belo e forte, mas também celibatário (BARROSO; MONTEIRO, 1956, p. 20). 
A “confissão” de Baltasar e a publicização da transição de gênero, assim como no romance, são pontos importantes da narrativa em quadrinhos. Talvez, por isso, essa experiência não seja narrada uma única vez, mas, ao contrário, por três vezes Baltasar foi levado a "confessar" ou se tentou "confessar" por ele. Na primeira dessas cenas, o capitão Nuno de Mascarenhas, à beira da morte, na travessia entre Brasil e Portugal, tenta contar ao guardião Vasco de Brito “o grave segredo" de Baltasar. No entanto, para alegria do pajem, o capitão morre enquanto tenta confessar a história, o que assegura a manutenção do segredo e permite a Baltasar viver em Portugal e na Índia como soldado (BARROSO; MONTEIRO, 1956, p. 15-16).

Esse "segredo" também organiza as relações entre Baltasar e Manuela, mas a situação só é verbalizada no desfecho da narrativa, quando um quadro sem desenhos explica o teor da "confissão" de Baltasar. Neste, o soldado não só afirma que é uma mulher, como também afirma que um amor mal resolvido, e a imposição de um casamento sem amor, algo que já vinha sendo sugerido ao longo dos quadrinhos, são as causas para a fuga da casa paterna e para a vida como homem e soldado (BARROSO; MONTEIRO, 1956, p. 44). A transição de gênero, no entanto, já era conhecida pelo leitor, uma vez que Baltasar é mortalmente ferido no combate ao tigre do Mandovi, e Arrais de Melo, durante a sua convalescência, o desnuda para cuidar de seus ferimentos.

O desconhecimento sobre a transição de gênero e a posterior “confissão" é, como podemos ver, o que constantemente movimenta a trama. Assim como acontece com a maior parte das donzelasguerreiras, a transição de gênero é narrada ao leitor através do ferimento, e a consequente convalescência, de Baltasar. Por sugestão de Manuela, que vê na expedição de caça ao tigre do Mandovi a possibilidade de aproximar Baltasar e Afonso, o soldado se alista na expedição comandada por Arrais de Melo. Nessa viagem pelo campo, há um clima de companheirismo, de cumplicidade, mas também de sedução entre os dois militares.

Baltasar ao ser ferido impede que lhe rasguem o casaco para que seja avaliado e tratado. Por isso, somente quando desmaia é que Afonso consegue, após dispensar os outros soldados, cuidar sozinho de Baltasar. Depois de todo o tratamento, Afonso usa suas roupas para vestir o amigo, e decide "guardar segredo". No dia seguinte, Baltasar, ao imaginar que seu "segredo" já era conhecido, narra a sua vida e "confessa” a transição de gênero para o capitão. Arrais de Melo, então, pergunta porque ele se alistou para a expedição, ao que Baltasar/Maria Úrsula responde que havia se alistado porque o amava. $\mathrm{O}$ capitão, a partir de então, passa a enxergar o soldado convalescente apenas e somente como a mulher amada, e logo os dois se beijam (BARROSO; MONTEIRO, 1956, p. 44-45).

Com o casamento de Baltasar/Maria Úrsula e Arrais de Melo, a ordem de gênero é reestabelecida, e assim como um amor mal resolvido foi a causa para a transição e para ir à guerra, um novo amor, agora bem resolvido, torna-se também a causa para a nova transição de gênero e para o fim de sua vida como soldado, uma vez que a personagem não só passa a se afirmar como mulher, como também passa a ser reconhecida como tal. A partir desse momento, Baltasar/Maria Úrsula passa a se submeter não só a Arrais de Melo, mas à ordem de gênero (LUGARINHO, 2018, p. 268-269). Quando recebe a pensão e a mercê do Paço de Pangim do rei D. João V, não é Baltasar/Maria Úrsula quem agradece e fala publicamente, mas é Arrais de Melo quem fala em seu nome, ainda que esteja ao seu lado (BARROSO; MONTEIRO, 1956, p. 47). Além disso, mesmo sendo autorizada a seguir usando traje varonil e espada, Baltasar/Maria Úrsula é, talvez no único momento em que a imagem se recusa a ser mera transcrição gráfica do texto, desenhada trajando vestido (BARROSO; MONTEIRO, 1956, p. 48). 
Podemos dizer que a transição de gênero da personagem é tolerada tanto pela excepcional capacidade guerreira e pela luta pela pátria, quanto pelo "retorno" a uma feminilidade submissa à ordem de gênero. Além disso, há também, assim como no romance, uma associação entre as "donzelasguerreiras” Baltasar/Maria Úrsula e Alonso de Guzmán/Catalina de Erauso, que serve para sobrepor Portugal à Espanha, uma vez que a donzela-guerreira luso-brasileira seria tão guerreira e valente quanto a espanhola, mas além disso seria também mais bonita, virgem, honesta e de bom procedimento. $\mathrm{E}$ também serve, principalmente, para justificar a tolerância e a recompensa régia à Baltasar/Maria Úrsula. O paralelismo estabelecido entre as duas personagens históricas e literárias e o reconhecimento religioso e real da transição de gênero de Alonso/Catalina, que recebeu não só permissão do papa Urbano VIII para seguir vivendo como homem, mas também uma pensão do rei espanhol Felipe IV pelos serviços prestados (MAIA, 2013, p. 4), tornam possível a tolerância e a celebração da vida de Baltasar/Maria Úrsula, assim como justificam a pensão e a mercê do Paço de Pangim dadas pelo rei português D. João V.

De forma geral, portanto, os quadrinhos de Barroso e Monteiro (1956), assim como o romance de Barroso (1932), valorizam os feitos militares de Baltasar, destacando sempre que ele é um dos primeiros soldados nas ações de combate; afirma o reconhecimento público da personagem, sugerindo que viveu, após dar baixa como soldado, cercado de glória e reconhecimento de seus contemporâneos; afirma a mulheridade e o casamento, ainda que reconheça a vida como homem e soldado; aponta para a permissão da manutenção dos trajes varonis e da espada com aprovação real, ainda que a personagem seja desenhada trajando vestido; justifica e valoriza a vida de Baltasar/Maria Úrsula através da vida de Alonso/Catalina; e afirma a desilusão amorosa como a causa primeira para as decisões da personagem. Desses procedimentos, fica patente que essas personagens, apesar de se oferecerem como forma de inclusão do feminino no imaginário nacional, acabaram reivindicadas pelos estados nacionais porque foram construídas em função de uma perspectiva masculina e hegemônica, "longe de serem transgressoras, indicam claramente a sua submissão à ordem de gênero” (LUGARINHO, 2018, p. 269).

\section{MARÍA ÚRSULA DE ABREU, MUJERES CÉLEBRES}

A edição María Úrsula de Abreu, da revista mensal Mujeres Célebres, foi publicada, no número 57, em dezembro de 1965, no México, e posteriormente, conforme informações da contracapa, foi distribuída também para a Espanha, Argentina e outros países hispânicos. Diante da falta de outras publicações e/ou traduções para o espanhol sobre a vida de Baltasar/Maria Úrsula, podemos dizer que a revista Mujeres Célebres foi a principal, e talvez única, forma de divulgação da personagem em língua espanhola, pelo menos até a massificação da internet e a publicação de sua história em blogs e sites como Wikipedia ${ }^{9}$. Assim como na revista anterior, há tanto uma restrição etária sobre quem pode ler "moralmente" a história de Baltasar/María Úrsula, uma vez que um carimbo na capa avisa que a revista é exclusivamente para maiores de 15 anos, como também prevalece uma perspectiva pedagógica, moralizante e tranquilizadora, através da informação existente na contracapa, que informa a aprovação pela "Secretaria de Educación Publica".

9 Outra importante fonte hispânica sobre Balthasar/Maria Ursula são os trabalhos de Carlos Figari (2007 e 2009). 
Na capa, como podemos ver na Figura 6 (ainda que possamos perceber a figura desenhada como um adolescente ou uma pessoa andrógina), a frase, colocada ao lado do desenho, ao dizer que se trata de uma heroína brasileira mais valente do que muitos homens, faz questão de afirmar a mulheridade da personagem ao informar o leitor que, apesar de "controverso", trata-se de uma mulher. Essa perspectiva se confirma, como veremos, ao longo da discussão dos quadrinhos, uma vez que enquanto as obras de Barroso (1932) e Barroso e Monteiro (1956) produzem certo suspense sobre o gênero da personagem, na revista mexicana Baltasar será sempre María Úrsula. Desde a capa, portanto, está indicada também que a transição de gênero é entendida como "disfarce”, uma vez que há um vestido abandonado na cadeira, ao mesmo tempo em que a personagem aparece cortando os longos cabelos.

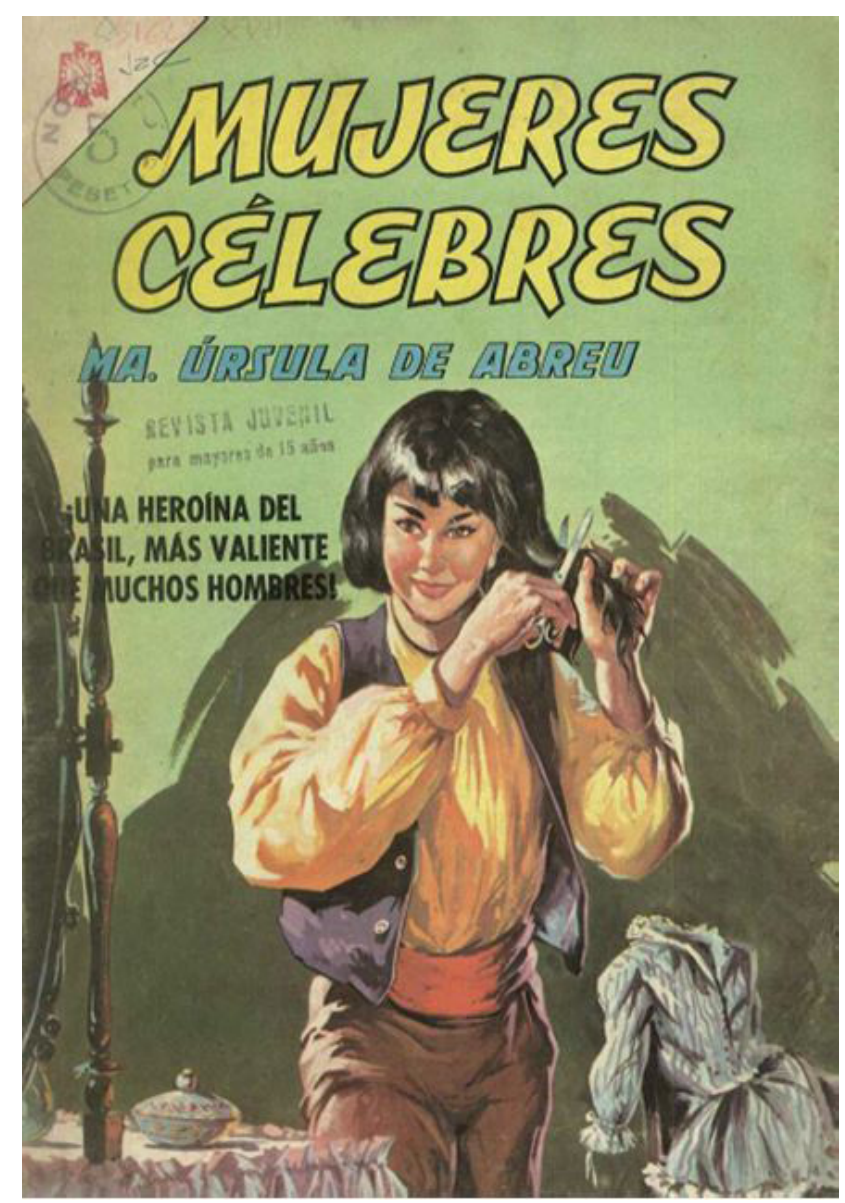

Figura 6 -Mujeres Célebres, n.57, 1965, capa.

Dentre os 32 relatos históricos publicados entre 1718 e 1965 sobre Baltasar/María Úrsula, somente o ensaio de Paulo Filho (1962), publicado no jornal Correio da Manhã, se refere à cena do corte de cabelo, ainda que seja bastante provável que esta ação tenha realmente acontecido. No entanto, o corte de cabelo não só aparece eventualmente em outros relatos de donzelas-guerreiras (GALVÃO, 1998; OLIVEIRA, 2001; VILALVA, 2004), como também aparece recorrentemente nos relatos sobre Alonso de Guzmán/Catalina de Erauso (Erauso, [1829]2002; MONTALBÁN, [1625]2012). A cena parece indicar não só que Baltasar/María Úrsula será lido também a partir de Alonso/Catalina, personagem 
amplamente conhecida no mundo hispânico, mas também que os vazios históricos sobre a personagem brasileira serão preenchidos por informações de outras "donzelas-guerreiras".

Além disso, podemos dizer que o autor do texto escrito e o quadrinista, cujos nomes não são indicados na publicação, pouco conhecem dos relatos históricos, e mesmo literários sobre a personagem, uma vez que há uma série de “inovações” narrativas sobre sua vida. Por exemplo, ao contrário dos outros relatos históricos e literários que indicam unanimemente que Baltasar/María Úrsula era natural do Rio de Janeiro, nos quadrinhos mexicanos a personagem teria nascido e vivido em Salvador ${ }^{10}$; ao contrário dos outros relatos históricos e literários que indicam que Baltasar/María Úrsula vivia com seu pai antes de embarcar para Portugal, nos quadrinhos a personagem, por ser órfão de pai e mãe, vive com os seus tios; por fim, ao contrário dos outros relatos, os quadrinhos mexicanos indicam que a personagem era a melhor costureira da cidade. Nenhuma dessas informações possui correspondência nos relatos anteriores, conhecidos, sejam brasileiros ou portugueses, sejam históricos ou literários, sobre Baltasar/María Úrsula.

Nesse mesmo sentido, como vimos, enquanto os relatos portugueses não procuram explicar as motivações da personagem nem para a transição de gênero nem para ir à guerra, os relatos brasileiros indicam três hipóteses para as causas primeiras da transição de gênero e da vida como soldado. No entanto, ao contrário das versões brasileiras, nos quadrinhos mexicanos, a personagem decide deixar Salvador diante da insatisfação com a vida que leva, seja porque está cansada das fofocas e intrigas que presencia quando atende suas clientes, seja porque entende que o tio explora o seu trabalho, uma vez que todo o dinheiro com a costura e a venda de roupas é dado ao patriarca (HARRELL, 1965, p. 3-4). Assim, viver como homem lhe permitiria viver melhor e mais livremente, longe das vaidades "femininas", longe da exploração patriarcal.

Na revista, a afirmação da mulheridade da personagem faz com que não só a vida como homem seja entendida como "disfarce", como também faz com que, ao contrário dos outros relatos que destacam a força e a valentia de Baltasar/María Úrsula, os trabalhos desempenhados pela personagem, tanto como marinheiro quanto como soldado, sejam sempre aqueles considerados como mais femininos. Enquanto no romance de Barroso (1932) e nos quadrinhos de Barroso e Monteiro (1956), Baltasar ganha a estima de seus companheiros ao lutar ao lado dos outros soldados e ao colocar fogo no navio inimigo, o que determina a vitória dos portugueses, nos quadrinhos mexicano, Baltasar só faz trabalhos na cozinha, uma vez que suas mãos seriam pequenas e não serviriam para outro serviço no navio (HARRELL, 1956, p. 7) ${ }^{11}$, além disso, não participa de atividades militares e só ganha a consideração de seus companheiros quando, durante uma tempestade, o seu corpo pequeno permite que ele escale o mastro e recolha a vela, o que impede a destruição do navio (HARRELL, 1956, p. 10-12). Assim, Baltasar pode até conseguir o reconhecimento de sua masculinidade, mas a princípio não o fará pela sua força ou capacidade guerreira.

\footnotetext{
10 No texto publicado em 20 de dezembro de 1966, na edição 22.610 do Correio de Manhã, por João Paraguassú, há uma extensa carta de uma leitora, a senhora Adelzia Bittencourt, que afirma ser "Maria Ursula de Abreu Lencastre [...] nascida na Bahia”. Além disso, informa também que morreu aos anos, "em plena mocidade e beleza, pois era muito bonita". Exceto por esta carta, não localizamos nenhum outro relato, além da revista mexicana, que indique que Baltasar/Maria Úrsula seria baiana.

11 Assim como Baltasar trabalha na cozinha porque não serve aos outros trabalhos por conta de seu corpo e de suas mãos pequenas, Pepe também trabalha na cozinha porque é velho demais para os outros serviços. No entanto, enquanto a idade do velho cozinheiro o protege das dúvidas sobre sua masculinidade, as "impossibilidades" físicas de Baltasar servem antes como acusações de sua falta de masculinidade.
} 
A afirmação da mulheridade da personagem, aparece não só desde a capa, mas também desde a primeira cena, quando Baltasar/María Úrsula é narrada como mulher e como "a melhor costureira da cidade" (HARRELL, 1965, p. 2). Na verdade, seus dotes de costureira facilitam o "disfarce" masculino que ela mesma costura, enquanto amadurece seu plano de viver como homem (HARRELL, 1965, p. 5). Não há, para o leitor, uma ambiguidade sobre o gênero da personagem, como nos outros textos literários, uma vez que tanto o texto escrito quanto os desenhos afirmam primeiro a mulheridade para depois falar do "disfarce”. Da mesma forma, não só a transição de gênero é rapidamente percebida pelo seu companheiro de cozinha, que diz se tratar de uma "menina" que "se disfarçou de homem" (HARRELL, 1965, p. 5), como também sua masculinidade é recorrentemente questionada pelos outros marinheiros e soldados, como podemos ver na Figura 7, onde Baltasar é chamado de "niña" porque teria se assustado com um rato na cozinha.

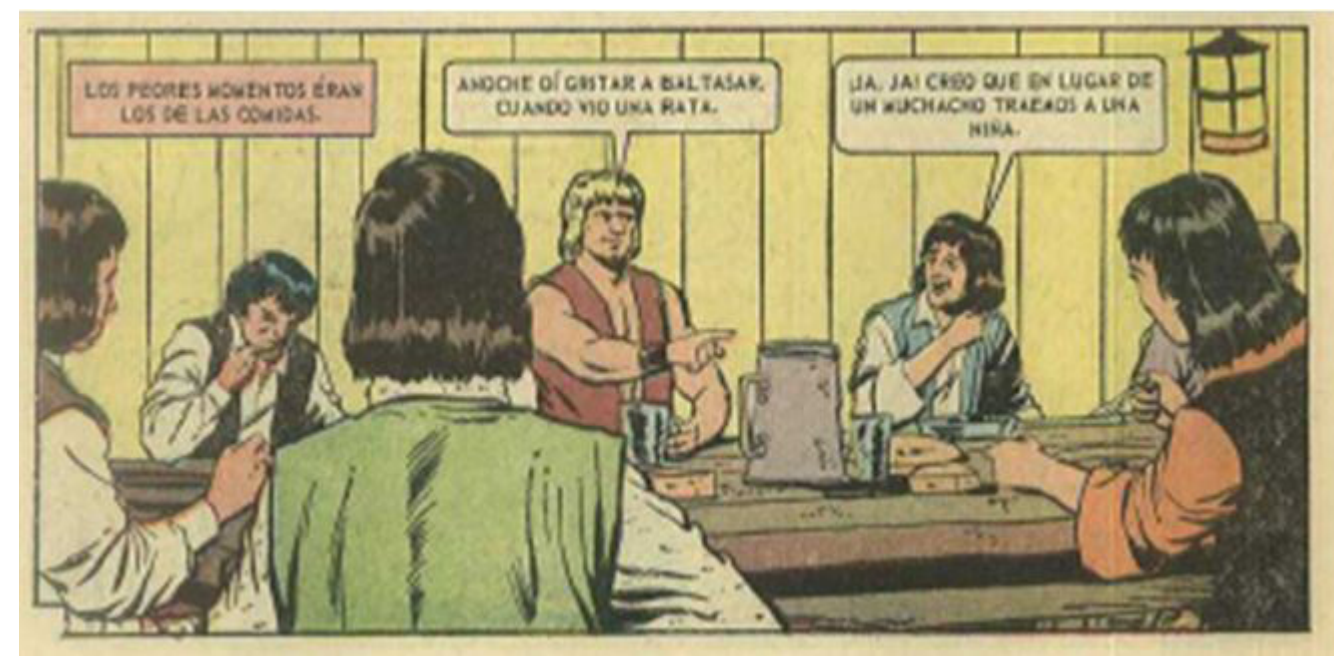

Figura 7 - Mujeres Célebres, n. 57, 1965, p 8.

Ao chegar em Lisboa, Pepe, o cozinheiro, leva Baltasar para sua casa, onde este se sente acolhido pela doçura da família. No entanto, Pepe e sua mulher, após uma confissão forçada da transição de gênero, desejam que Baltasar volte a viver como mulher, ocupando o lugar deixado pela filha falecida. Baltasar rechaça essa possibilidade, alegando que está "viciado" em trabalhos masculinos e que deseja conhecer o mundo, o que só será possível vivendo "disfarçada" de homem. Apesar das "ameaças" de Pepe, que afirma que ela está cometendo um grave erro, e de sua mulher, que afirma que essa escolha lhe privará de um dia casar, sugerindo, portanto, que o casamento é o desejo de toda mulher (HARRELL, 1965 , p. 16), Baltasar deixa a casa e o aconchego familiar dos amigos.

Em seguida passa a trabalhar em um estaleiro, quando decide finalmente se alistar como soldado. $\mathrm{Na}$ Índia, como se a capacidade guerreira da personagem precisasse ser justificada para o leitor, uma vez que anteriormente as únicas atividades de Baltasar/María Úrsula eram as de costura e as da cozinha, os soldados recém-chegados passam por um rigoroso treinamento militar de três meses. Quando vai a campo, Baltasar se destaca em combate, salvando o capitão da morte por duas vezes. De volta à Goa, Baltasar, como prêmio pela sua destacada atuação, passa a trabalhar como assistente do governador Arrais de Melo, de quem, em seus pensamentos, elogia a beleza. 
Junto ao governador, Baltasar ataca o forte de Amboino, onde não só é o primeiro a avançar sobre a fortaleza, mas também a salvar a vida de Arrais de Melo. Ao contrário dos textos de Barroso (1932, 1956), Baltasar se fere mortalmente no combate de Amboino, e não na caça do tigre do Mandovi. Todavia, assim como nas outras obras, é o ferimento que leva à "descoberta" e à "confissão" da transição de gênero. Ao despertar da convalescência, temendo ser novamente ridicularizado pelos outros soldados, Baltasar resolve dar baixa, ainda que Afonso assegure que só ele e o médico sabem de seu "segredo" (HARRELL, 1965, p. 31). A nova transição de gênero se dá pelo temor da violência dos outros soldados, e não, como aparece nos textos literários e históricos brasileiros, por amor ao seu capitão.

No dia seguinte, sem ter confessado o seu amor a Arrais de Melo, Baltasar resolve embarcar de volta para Lisboa. Em rápido desfecho, entretanto, o governador, antes do embarque de Baltasar, diz que a ama e a pede em casamento, ao que Baltasar/María Úrsula, sempre trajando roupas masculinas e espada, responde que só poderá dar uma resposta ao pedido de casamento quando terminar de costurar um lindo vestido. Arrais de Melo, no entanto, duvida que ele seja capaz de segurar uma agulha. Nesse desenlace, parece-nos que o encantamento e o amor de Arrais de Melo, apesar de toda a afirmação da mulheridade de Baltasar/Maria Úrsula, é também pelo que existe de masculino na personagem, uma vez que também oscila entre chamá-lo de Baltasar e María Úrsula, mas também porque duvida que a personagem seja capaz não só de manusear uma linha de costura, mas também de viver como uma mulher igual as outras. Da mesma forma, parece-nos também que, para Baltasar/María Úrsula, costurar novamente suas roupas femininas se configuraria como um novo ritual, uma nova preparação, para a nova transição de gênero. Assim, à medida que tece suas roupas, também tece sua identidade de gênero.

A narrativa termina sem que seja confirmado o casamento, e com Baltasar/María Úrsula trajando roupas masculinas e espada. Além disso, nem o texto visual nem o escrito nos dá informações sobre como viveu após dar baixa como soldado, e sobre as recompensas oferecidas pelo rei português $\mathrm{D}$. João V. A história, portanto, termina com a promessa de uma nova transição de gênero. Logo, podemos dizer que de forma geral a narrativa mexicana dialoga pouquíssimo com os textos literários sobre a personagem, além de contradizer todos os relatos históricos sobre as motivações para as duas transições de gênero e para a vida como soldado. Mas, mais do que a "fantasia" criada a partir da biografia de María Úrsula/Baltasar, os quadrinhos mexicanos preferem investir no processo de transição de gênero e na reinserção no feminino, como se houvesse uma promessa de redenção que rememora (e pretende superar) os maus augúrios vaticinados pela esposa do cozinheiro Pepe.

\section{CONSIDERAÇÕES FINAIS}

Como mostramos, as fontes portuguesas anteriores ao romance de Barroso (1932) não se preocupam em explicar as motivações da personagem para a vida como homem e soldado. Além disso, com exceção do texto de Froes Perim (1740), não narram um possível casamento, assim como também não descrevem sobre como a personagem viveu após dar baixa como soldado. No que se refere, no entanto, aos relatos históricos portugueses produzidos depois da obra de Barroso (1932) e antes da obra de Harrel (1965), podemos dizer que, com exceção do texto de Pimenta (1942), não só tentam explicar as motivações da personagem para a transição de gênero e para a ida à guerra, como também inovam nesse aspecto, uma vez que Castro Júnior (1965, p. 9), ineditamente, atribui as 
decisões de Baltasar/Maria Úrsula à grave comoção ocasionada pela leitura de romances de cavalarias e de narrativas de feitos das Cruzadas.

Além disso, seguem de perto o relato de Froes Perim (1740) e os relatos brasileiros, afirmam o casamento com Arrais de Melo, assim como também narram, novamente, com exceção do texto de Pimenta (1942), a fama conquistada em vida em várias partes do mundo português após dar baixa como soldado, como pudemos ver em Correia (1948, p. 573). A grande diferença em relação aos textos anteriores é que, apesar das acusações de falta de verossimilhança de Pimenta (1942), os autores portugueses mais recentes parecem tomar o livro de Barroso (1932), e as fontes brasileiras, como fonte histórica, divulgando trechos do romance como se fossem documentos.

As fontes brasileiras anteriores à obra de Barroso (1932), como vimos, insistem em produzir explicações para a transição de gênero e para a vida como soldado, o que leva a três diferentes versões (SOUZA SILVA, 1841; MACEDO, 1876; SABINO, 1899). Além disso, a grande maioria também afirma o casamento por amor e a vida após dar baixa como soldado cercada do reconhecimento de seus contemporâneos. No que se refere aos relatos históricos brasileiros produzidos depois da obra de Barroso (1932) e antes da publicação da revista mexicana (HARREL, 1965), podemos dizer que os autores seguem utilizando as três diferentes versões para explicar as motivações da personagem tanto para a transição quanto para a vida como soldado, assim como também seguem em sua maioria narrando o casamento por amor e a fama após dar baixa como soldado.

A grande diferença em relação ao período anteriormente analisado é que há nos novos relatos uma maior afirmação da mulheridade da personagem, da qual é sintomática os diferentes textos produzidos por Barroso. Enquanto os textos literários do autor produzem dissonâncias sobre a compreensão da transição e do gênero de Baltasar/Maria Úrsula, os textos históricos vão cada vez mais, ao longo dos anos, reafirmar a mulheridade e negar a sua masculinidade. No texto de 1948, por exemplo, a personagem é um “vulto feminino", no texto de 1949, o autor utiliza as expressões "mulher" e "mulher soldado", e afirma que o nome Baltasar é um pseudônimo, por fim, no texto de 1958, o autor não só fala da personagem apenas como "mulher", como também não faz qualquer referência ao nome Baltasar. Assim, de forma geral, podemos dizer que os textos mais recentes se tornam cada vez mais normativos quando se referem ao gênero e a transição de gênero da personagem.

A revista A Senhora de Pangim, escrita por Barroso e ilustrada por Monteiro, publicada em 1956, em Edição Maravilhosa, está, como vimos, muito presa em sua narrativa ao romance de Barroso (1932), uma vez que os textos escritos retirados do romance prevalecem sobre as gravuras, tornando-as muitas vezes dispensáveis. Da mesma forma, a narrativa está muito próxima das fontes históricas do romancista, Souza Silva (1862), Teixeira de Mello (1881) e Rio Branco (1891), mas, especialmente no que se refere às motivações para a transição de gênero e a vida como soldado, a Macedo (1876). Sobre o gênero e a transição de gênero de Baltasar/Maria Úrsula, ainda que prevaleça uma visão normativa, podemos dizer que há um jogo dúbio na narrativa, feito de suspenses, ocultamentos, segredos e confissões, que pode facilitar uma leitura contra as normatividades do próprio texto.

Numa comparação com os outros relatos históricos de Barroso (1942, 1948, 1949, 1958), tanto o texto visual quanto o texto escrito são menos normativos. Por fim, a partir exclusivamente desta revista, podemos dizer que Baltasar/Maria Úrsula pode ser entendida como uma "donzela-guerreira", uma vez que há um reconhecimento de sua identidade masculina e de sua masculinidade pelos outros 
personagens, mas, ao mesmo tempo, esta transição de gênero, ainda que autorizada pelo rei $\mathrm{D}$. João $\mathrm{V}$, aparece circunscrita unicamente ao período de guerras, visto que a personagem após dar baixa como soldado é ilustrada com vestidos, e não mais com “trajes masculinos” e espada.

A revista María Úrsula de Abreu, cuja autoria não é informada, publicada em 1965, em Mujeres Célebres, está mais próxima de outros relatos de donzelas-guerreiras, especialmente das narrativas sobre Alonso de Guzmán/Catalina de Erauso, do que dos textos históricos e literários sobre Baltasar/Maria Úrsula, como pudemos ver através das muitas "inovações" da revista. Assim, podemos dizer também que há pouco diálogo com os outros dois textos literários sobre a personagem. Dessa forma, a motivação para a transição de gênero e para a vida como soldado, ao contrário das três possibilidades apontadas pelos relatos históricos e literários brasileiros, é a insatisfação da vida que leva como costureira e a insatisfação com a ordem patriarcal exercida pelo seu tio.

Há na revista mexicana também uma constante reafirmação da mulheridade da personagem; não há, portanto, "segredos" para os leitores sobre a transição, que é o tempo todo entendida e narrada como "disfarce". No entanto, apesar de todo esforço inicial dos narradores em reafirmar a mulheridade da personagem, Baltasar/María Úrsula só decide abandonar a vida como homem e soldado porque tem medo da violência de seus companheiros. Não é o amor ou o pedido de casamento a motivação primeira para a nova transição de gênero. Apesar disso, Baltasar termina a história trajando roupas masculinas e espada, ainda que haja uma promessa de costurar um novo vestido e de viver como esposa, o que o próprio Arrais de Melo duvida. Assim, podemos dizer que a personagem pode ser entendida a partir da ideia de "transgeneridades guerreiras", uma vez que não só vai à guerra, como também a identidade masculina é vivida sempre que possível e desejada, e para além da temporalidade da guerra, o que mostra que a performatividade de gênero da personagem é antes de tudo uma escolha narrativa.

Os exames procedidos em todas essas narrativas apenas confirmam que mesmo havendo uma atitude transgressora por parte da personagem, ao deliberadamente transitar entre gêneros, os motivos e desdobramentos de sua ação devolvem-na à ordem que transgredira. Como evidentemente vinculada a ações bélicas típicas, nas quais se destaca, parece ser necessário, nessas várias narrativas, reenviá-la à condição feminina mesmo que haja fontes que contradigam a restauração da ordem de gênero. $\mathrm{O}$ que essas narrativas, enfim, oferecem para o estudo das representações literárias da transgeneridade é o destaque dado ao embate entre a potência da personagem e a narrativa, que vence, conformando-a.

\section{REFERÊNCIAS}

ALMANAQUE Lobinho. Edição Gigante, p. 8, 1942.

BARROSO, Gustavo. A Senhora de Pangim. Rio de Janeiro: Guanabara, 1932.

BARROSO, Gustavo. A Senhora de Pangim. Lisboa: Agência Geral das Colônias, 1940.

BARROSO, Gustavo. “Amboino: o noticiário da guerra”. A Manhã. Rio de Janeiro, n. 173, p. 4, 1942.

BARROSO, Gustavo. A mulher na história. A Cigarra, n. 173, p. 108-109, 1948.

BARROSO, Gustavo. Uma heroína brasileira na Índia. O Cruzeiro, n. 7, p. 32, 36, 54, 1949.

BARROSO, Gustavo; MONTEIRO, Gutenberg. A Senhora de Pangim: romance histórico de Gustavo Barroso. Edição Maravilhosa (Extra), n. 116, jan. 1956. 
BARROSO, Gustavo. O govêrno feminino duma capitania brasileira. O Cruzeiro, n. 34, p. 77, 1958.

CASTRO JÚNIOR, Augusto César. Uma heroína luso-brasileira na Índia portuguesa. Actas do V Colóquio Internacional de Estudos Luso-brasileiros, Coimbra, 1965.

COARACY, Vivaldo. O Rio de Janeiro no século dezessete. v. 6. Rio de Janeiro: José Olympio, 1965.

CORREIA, Germano. História da colonização portuguesa na Índia. v. 5. Lisboa: Agência Geral das Colónias, 1948.

COSTA, Luiz Mário Ferreira. Relações intelectuais assimétricas: a "polêmica” histórica entre Alfredo Pimenta e Gustavo Barroso. Oficina do Historiador (Porto Alegre), v. 9, n. 1, p. 115-130, 2016. Disponível em https:// revistaseletronicas.pucrs.br/ojs/index.php/oficinadohistoriador/article/view/22777. Acesso em $09 \mathrm{fev}$ 2021.

ERAUSO, Catalina. Historia de la Monja Alférez, Catalina de Erauso, escrita por ella misma. Madrid: Cátedra, 2002.

FIGARI, Carlos.@soutr@s cariocas: interpelações, experiências e identidades homoeróticas no Rio de Janeiro: século XVII ao XX. Belo Horizonte: UFMG, 2007.

FIGARI, Carlos. Eróticas de la disidencia en América Latina: Brasil, siglos XVII al XX. Buenos Aires: CLACSO, 2009.

FROES PERIM, Damiao. Theatro Heroino, Abcedario das Mulheres Ilustres em Armas, Letras, Acçoens heroicas, e artes liberaes. t. 2. Lisboa: Regia Officina Sylviana, 1740.

GALVÃO, Walnice. A donzela-guerreira: um estudo de gênero. São Paulo: Senac, 1998.

GALVÃO, Walnice. De Frida Kahlo à Donzela Guerreira. Revista Cult, Edição 210, 2016.

GAZETA DE LISBOA. Lisboa, n. 12, 24 de março 1718, p. 96, 1718.

HARRELL, Rafael (Dir.). María Úrsula de Abreu. Mujeres Célebres (Mexico), n. 57, dez. 1965.

LEVY, Fortunée. Maria Úrsula de Abreu Lencastre. In: Anais do Museu Histórico Nacional, v. IV, Rio de Janeiro: Imprensa Nacional, 1943.

LUGARINHO, M. C. Ordem, gênero e transgressão em A Senhora de Pangim, de Gustavo Barroso. Via Atlântica (São Paulo), n. 33, p. 253-272, 2018. DOI: 10.11606/va.v0i33.139982. Disponível em: https:// www.revistas.usp.br/viaatlantica/article/view/139982. Acesso em: 12 fev. 2021.

MACEDO, Joaquim Manoel. Anno Biographico Brazileiro. v. 3. Rio de Janeiro: Typographia e Lithographia do Imperial, 1876.

MAIA, Helder Thiago. Retratos da sexualidade: Uma Análise das Obras 'La Monja Alférez' de Juan Pérez de Montalbán e 'Historia de la Monja Alférez, Catalina de Erauso, escrita por ella misma' de Catalina de Erauso. Feminismos (Salvador), v. 1, n.o 3, p. 72-87, 2013. Disponível em: https://periodicos.ufba.br/index.php/ feminismos/article/view/29938. Acesso em 14 fev. 2021.

MAIA, Helder Thiago. O vulto da Bahia e o lugar da mulher: Maria Quitéria/Soldado Medeiros no carnaval carioca. Cadernos De Literatura Comparada (Porto), n. 43, p. 87-106, 2020. Disponível em https://ilccadernos.com/index.php/cadernos/article/view/699. Acesso em 10 fev 2021.

MAIA, Helder Thiago. Baltasar do Couto Cardoso: transgeneridades guerreiras no império colonial português. In: CARVALHO, Danniel; LIMA, Pedro. Linguagem, gênero e sexualidade. Salvador: EdUFBA. No prelo.

MASSON, Nonato. Muié macho, sim sinhô. Jornal do Brasil, Edição 105, p. 18, 1962. 
MEIRELES, Cecilia. Caminho de Goa. Diario de Noticias, Suplemento Literário, Edição 09964, $1^{\circ}$ de maio de 1955, p. 1 e 4, 1955.

MEIRELES, Cecilia. Uma antepassada da donzela-guerreira. In: Estudos e ensaios folclóricos em homenagem a Renato Almeida. Rio de Janeiro: Ministério das Relações Exteriores, 1960.

MEIRELES, Cecilia. Uma antepassada da donzela-guerreira. Revista Brasileira de Folclore, Ano IV, n. 8/10, p. X, 1964.

MELO, Mario. A Senhora de Pangim. Diario de Pernambuco, Edição 96, 30 de abril de 1932, p. 3, 1932.

MONTALBÁN, Juan Pérez. La Monja Alférez. Barcelona: Red, 2012.

OLIVEIRA, Valdeci. Figurações da donzela-guerreira nos romances Luzia-Homem e Dona Guidinha do Poço. (Dissertação). Universidade Estadual de Campinas, 2001.

PACHECO, Armando. A Noite, Edição 10.553, p. 3, 1941.

PARAGUASSÚ, João. Os bibliófilos. Correio da Manhã, Edição 22.610, p. 6, 1966.

PAULO FILHO, Manuel. Em Goa, uma heroína carioca. Correio da Manhã, Edição 21.104, p. 2, 1962.

O ORIENTE PORTUGUÊS. Goa: [s. n.], 1904-1916. Disponível em: http://memoria-africa.ua.pt/Library/ OOP.aspx. Acesso em: 14 dez. 2020.

PIMENTA, Alfredo. A senhora de Pangim. Brasilia, (Coimbra), v. 1, p. 179-187, 1942.

RIO BRANCO, Barão do. Ephemerides Brazileiras. Jornal do Brasil, p. 2, $1^{\circ}$ setembro de 1891,

ROSA, Guimarães. Grande Sertão: Veredas. Rio de Janeiro: José Olympio, 1956.

SABINO, Ignez. Mulheres Illustres do Brazil. Rio de Janeiro: Garnier, 1899.

SALDANHA, Manoel Gabriel. História de Goa: política e arqueológica. v. 1. Goa: Tipografia Rangel, 1898. Versão citada: New Delhi: Asian Educational Services, 1990.

SILVA, Anabela. A donzela guerreira: confluências literárias. (Dissertação) Universidade do Porto, 2010.

SOUZA SILVA, Joaquim Norberto. D. Maria Ursula de Abreu Lencastre. In: Revista Trimensal de História e Geografia. (Rio de Janeiro), 1841.

SOUZA SILVA, Joaquim Norberto. Brasileiras Célebres. Rio de Janeiro: Garnier, 1862.

TADASCO, André Nilo. Hoje no passado O Estado, Florianopolis, n. 11.695, p. 3, 1953.

TEIXEIRA DE MELLO, José Alexandre. Ephemerides Nacionaesi (Julho-Dezembro). t. 2. Rio de Janeiro: Typographia da Gazeta de Noticias, 1881.

VILALVA, Walnice. Marias: estudo sobre a donzela-guerreira no romance brasileiro, (Tese). Universidade Estadual de Campinas, 2004. 